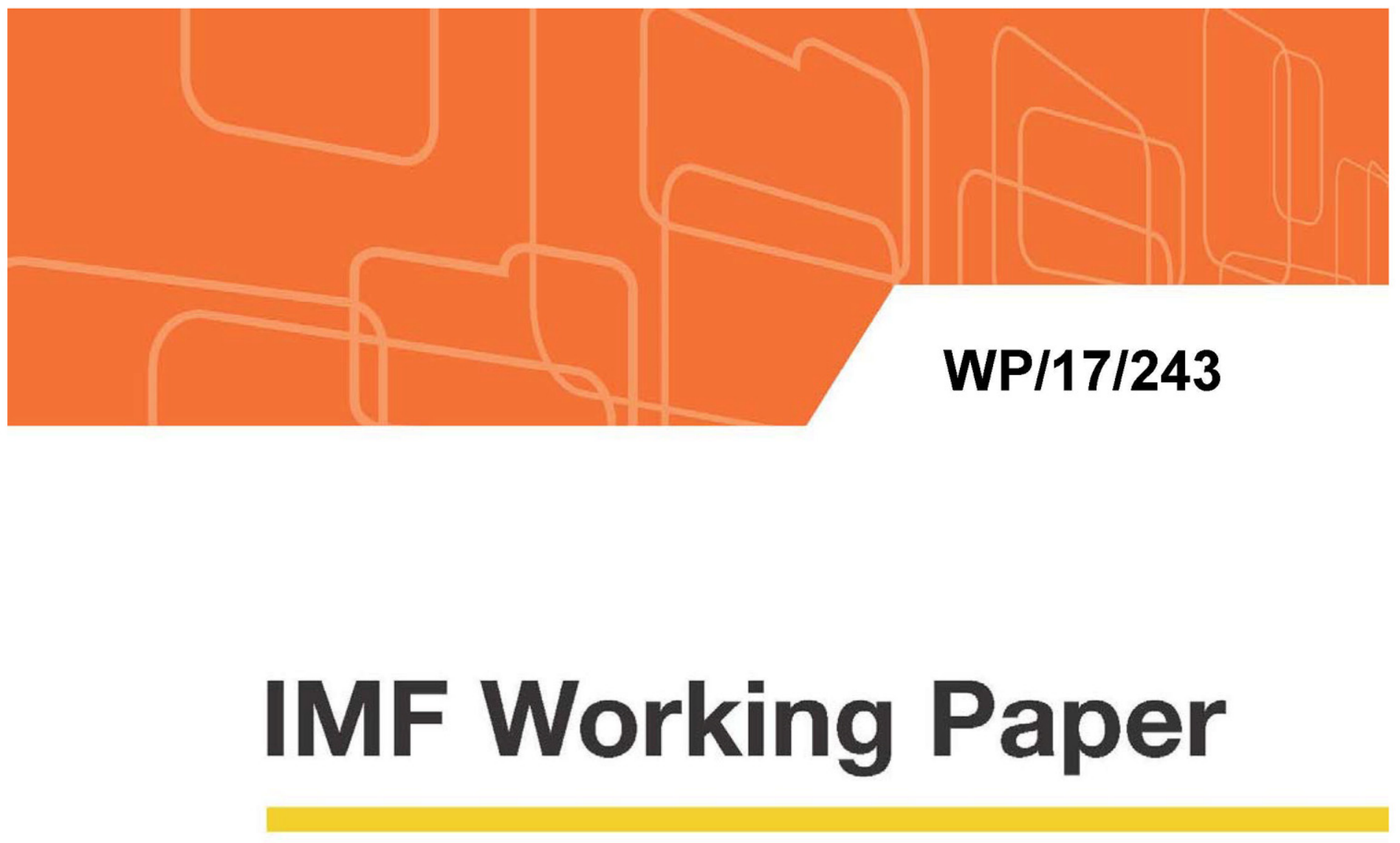

\title{
Enforcing Public-Private Partnership Contract: How do Fiscal Institutions Matter?
}

\author{
by Manabu Nose
}

IMF Working Papers describe research in progress by the author(s) and are published to elicit comments and to encourage debate. The views expressed in IMF Working Papers are those of the author(s) and do not necessarily represent the views of the IMF, its Executive Board, or IMF management. 


\title{
WP/17/243
}

\section{IMF Working Paper}

\section{Enforcing Public-Private Partnership Contract: How do Fiscal Institutions Matter?}

\author{
by Manabu Nose
}

IMF Working Papers describe research in progress by the author(s) and are published to elicit comments and to encourage debate. The views expressed in IMF Working Papers are those of the author(s) and do not necessarily represent the views of the IMF, its Executive Board, or IMF management.

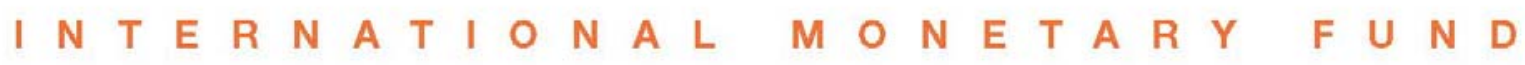




\title{
IMF Working Paper
}

\author{
African Department \\ Enforcing Public-Private Partnership Contract: \\ How do Fiscal Institutions Matter? \\ Prepared by Manabu Nose \\ Authorized for distribution by Ana Lucia Coronel
}

October 15, 2017

\begin{abstract}
IMF Working Papers describe research in progress by the author(s) and are published to elicit comments and to encourage debate. The views expressed in IMF Working Papers are those of the author(s) and do not necessarily represent the views of the IMF, its Executive Board, or IMF management.
\end{abstract}

\begin{abstract}
Public-private partnerships (PPPs) have increased rapidly in emerging and developing countries, creating both opportunities and fiscal challenges. One of the main challenges is that while governments have increased commitments in guarantees and direct subsidies to promote PPPs, contractual disputes remain high with significant costs. This paper examines how fiscal institutions affect the selection of PPP contracts and the probability of contract disputes using about 6,000 PPP contract-level data. The analysis shows that larger government financing needs, lower budget transparency and bureaucratic efficiency are associated with higher probability for governments to offer guarantees. Propensity score matching results show that disputes are more common for guaranteed contracts due to adverse selection and contingent liability effects. PPP management quality and budget transparency are found to be key determinants for a longer survival of PPPs.
\end{abstract}

JEL Classification Numbers: F21, H54, O10, O19

Keywords: Public-private partnerships, adverse selection, public investment management, fiscal risk, propensity score matching

Author's E-Mail Address: MNose@imf.org 


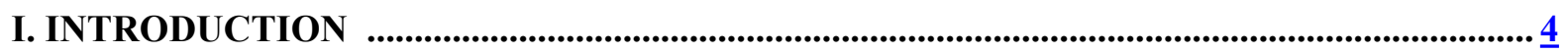

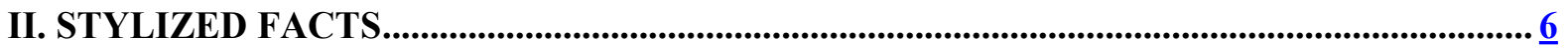

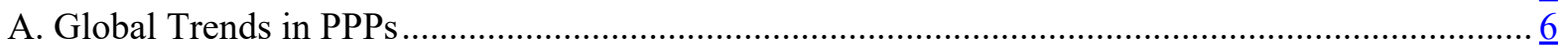

B. Country-level Determinants of Contractual Disputes............................................................ 7

C. Contract Design and Fiscal Institutions ................................................................................

III. THEORETICAL FRAMEWORK

A. Procurement

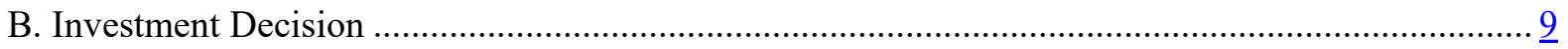

C. Conditions for Outbreak of Disputes ……..................................................................... 10

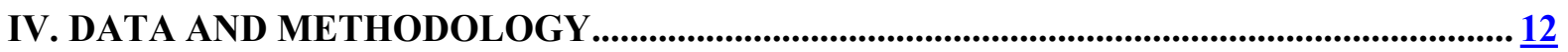

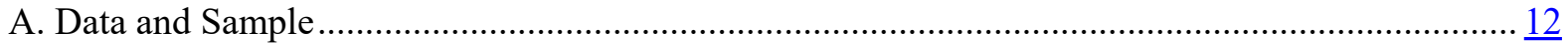

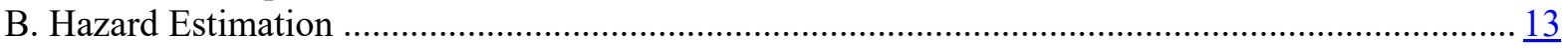

C. Bias Adjustment using the Propensity Score Matching .............................................................. 13

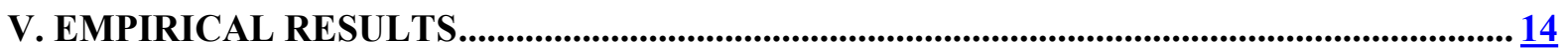

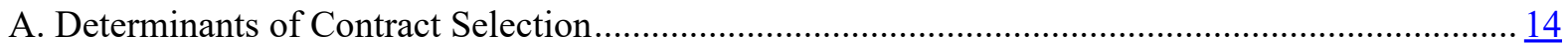

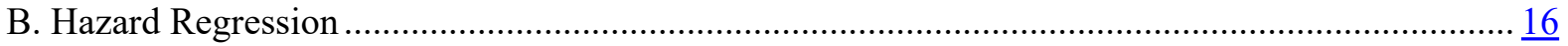

C. Robustness Checks in Alternative Specifications................................................................. 17

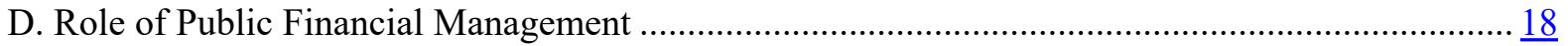

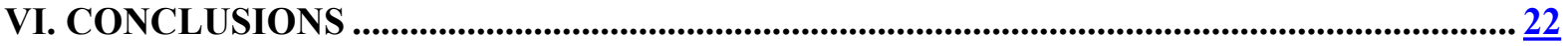

\section{FIGURES}

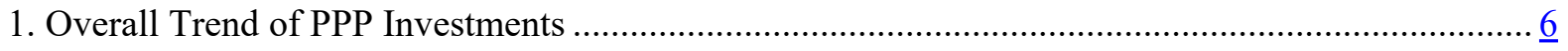

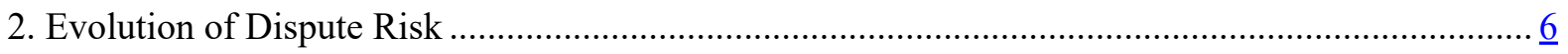

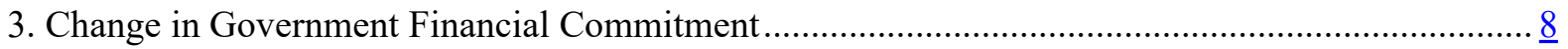

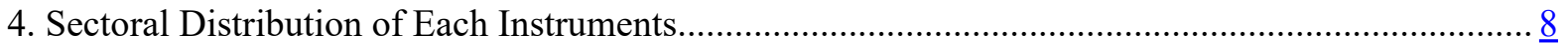

5. Change in Hazard Ratio by Contract Types ......................................................................... 19

6. Distribution of the Quality Scores on Fiscal Institutions ............................................................ 21

\section{TABLES}

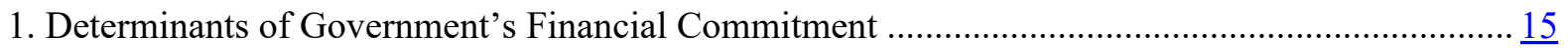

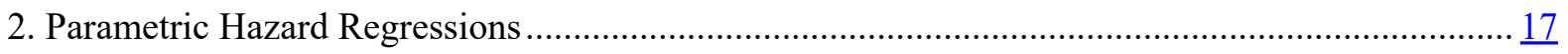

3. Effect of the Quality of Fiscal Institutions …......................................................................... 21

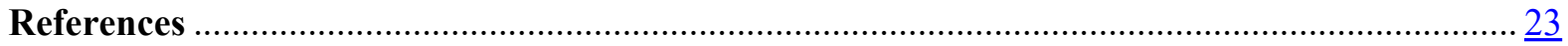

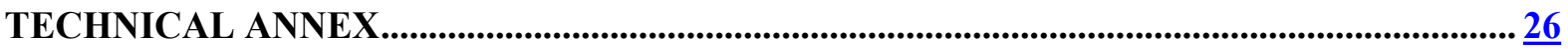

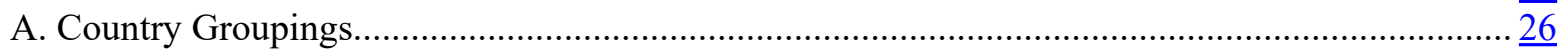

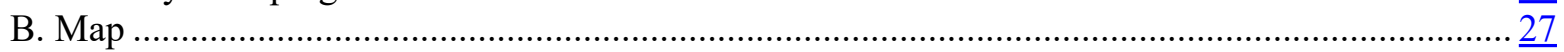

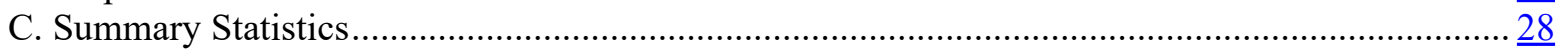

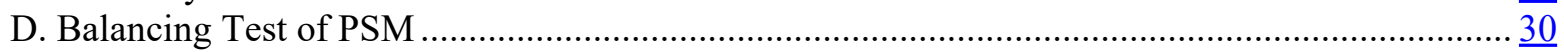

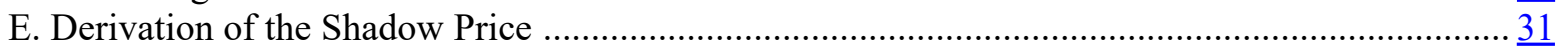

F. Role of PPP Investment Management in case of Concessions ................................................ $\underline{32}$ 


\section{INTRODUCTION ${ }^{1}$}

Public-private partnerships (PPPs) can augment public investment and improve the efficiency of infrastructure spending. Large-scale power, transportation or telecom projects are capital intensive and technically complex, which prima facie lend them to be awarded to private sponsors. However, the quasi-public nature of such assets and long economic lifecycle mean that investors are exposed to a high regulatory uncertainty and lengthy payback periods.

Since the early 1990s, PPPs have increased in both middle (MICs) and low income countries (LICs) as an alternative source of financing to scale up public capital stock (IMF 2014a, b). Whereas PPP programs have become an attractive modality for public infrastructure provision, governments and concessionaires often go into disputes at some point during the lifecycle of projects, as a result of which contracts are either renegotiated or terminated.

What determines the success rate of PPPs? Is there anything in the design of PPPs that make some projects more successful than others in raising a country's output? In the 1970s and 1980s, opportunistic regulatory actions, if not outright expropriations, were the biggest concern for foreign investors in developing countries (Jensen, 2008; Li, 2009). While the incidence of expropriations appears to have subsided, breach of contract, such as changes or forced cancellations of concession agreements, has become more frequent since 1990s. Recent literature has focused on political institutions and exogenous economic shocks that drive government decisions to break or uphold contracts (Jensen et al, 2017). This paper provides new empirical evidence that the weakness in governments' fiscal institutions budget transparency and public investment management (PIM) of PPPs - can undermine the quality of project selection and increases contract disputes of PPPs.

The quality of fiscal institutions is critical in managing disputes as PPPs require a strong fiscal and legal basis (Cangiano et al, 2006) and a sound PIM system (World Bank, 2014a). For an optimal design of PPPs, governments should develop central PPP units, incorporate the fiscal risk of PPPs into the fiscal framework, and integrate PPPs into traditional PIM framework. PPP-specific legal and regulatory frameworks exist, but developing countries still lack adequate capacity in managing the fiscal risk. Low capacity results in contractual failure that discourages private investments and reduces social welfare by disrupting public utility services. Fiscal mismanagement is thus a major risk for PPPs that can inhibit efficiency gains (called "value for money") from materializing. ${ }^{2}$ The following sections will discuss how weak fiscal institutions could undermine the outcomes of PPPs.

\footnotetext{
${ }^{1}$ The author thanks Alexander Plekhanov, Isabel Rial, Laura Papi, Geremia Palomba, Roger Nord, Genevieve Verdier, Wendell Daal, Laura Doherty, David Gentry, Axel Schimmelpfennig, Leandro Medina, Francisco Arizala, Kenichi Ueda, Yasuyuki Sawada, Hiroaki Miyamoto, Yasushi Iwamoto, Yoshito Takasaki, Rudolfs Bems, Nobuhiko Fuwa, Nozomi Nose, Alberto Simpser, Moritz Zander, seminar participants at the University of Tokyo, the 2015 Annual Bank Conference on Development Economics (ABCDE), the IMF's African Department, and the $11^{\text {th }}$ Midwest International Economic Development Conference for useful comments and suggestions.

${ }^{2}$ The value for money means the cost-effectiveness of public service (better quality services with lower cost) under PPPs compared with traditional public procurement (World Bank, 2014b).
} 
Recent literature has focused on country-level factors such as democracy, cohesive political institutions, and state fragility as the key determinants of the success of PPPs. ${ }^{3}$ Some papers have shown that natural resource dependency also matters as resource-rich countries tend to be less sensitive to reputational costs from breaching contracts, which can increase the risk of expropriations and disputes especially during commodity price booms (Jensen and Johnston, 2011; Frankel, 2012). As for micro-level factors, the theoretical literature has stressed that contract design matters in affecting the efficiency of PPPs (Hart, 2003; Iossa and Martimort, 2015; Valero, 2015). Only a few studies have empirically examined contractual characteristics as determinants for the performance of PPPs (Guasch, Laffont, and Straub, 2007), and the role of fiscal institutions in mitigating dispute risk is yet to be evaluated.

Using a dataset of about 6,000 PPP contracts from 113 emerging and developing countries, this paper examines how fiscal institutions affect the governments' involvements in PPP contracts and change the survival rate. First, a theoretical model presents how PPPs are chosen over public procurement and how governments optimally commit on PPPs when fiscal risks accumulate due to the provision of guarantees vs. direct subsidies. Second, it estimates (i) the selection of PPP contract schemes and (ii) the effect of governments' fiscal commitments on the probability of contract disputes. It also tests how improvements in fiscal institutions can reduce disputes using two fiscal institution measures: a score on PIM quality related to PPPs (compiled from EIU (2012, 2014, 2015), IMF (2015), and World Bank (2016)) and the budget transparency index (Wang et al, 2015). It applies the propensity score matching (PSM) to address endogeneity issues due to the selection of contract types.

Although the theoretical framework suggests that the provision of guarantees should promote private participation in infrastructure, the empirical results find that disputes tend to increase for guaranteed contracts due to higher fiscal risks. The analysis shows that the negative consequence of guarantees is associated with adverse selection on riskier projects and the accumulation of contingent liabilities, highlighting the importance of improving PPP management quality and budget transparency. The policy implications differ by geographical areas. Many PPPs in matured markets (such as developing Asia and Latin America) have accompanied guarantees, and thus budget transparency should be improved to adequately manage fiscal risk of PPPs. In sub-Saharan Africa, concession contracts face higher dispute risk than other regions for lower capacity in assessing project risk, calling for a stronger PIM system to improve selection and operation of PPPs.

The paper is organized as follows. Section II provides stylized facts on PPPs. Section III presents a model to derive theoretical predictions on the role of fiscal commitments and fiscal institutions in PPP contracts. Sections IV and V carry out empirical analyses to test theoretical hypotheses. Section VI concludes.

\footnotetext{
${ }^{3}$ Foreign investments are shielded from political risk in democratic countries (Jensen 2008), in countries with stronger property rights and legislative check-and-balance system and with less frequent political turnovers ( $\mathrm{Li}$ and $\mathrm{Resnick}, 2003$; $\mathrm{Li}$, 2009; Humphreys and Bates, 2005). The likelihood of disputes also relates to fragility and inclusiveness of political institutions (Besley and Persson 2009, 2010).
} 


\section{STYLIZED FACTS}

\section{A. Global Trends in PPPs}

The last 30 years have seen a dramatic rise of PPPs in emerging and developing countries. After a slowdown during the 1997 Asian financial crisis, PPPs have started to increase in developing Asia and Latin America (LAC), especially after the 2008 global financial crisis. Having spread across the globe, PPP investments doubled from about $\$ 50$ billion per year on average during 2000-05 to about $\$ 100$ billion per year on average during 2010-15. Most projects are in large MICs, such as BRICs, Argentina, Mexico, Colombia, Philippines, Indonesia, Turkey, and Nigeria (see appendix Figure A1). Countries in developing Asia and LAC have experienced a spike in PPPs since 2004, reaching about \$50-60 billion per year, while PPPs remain relatively small in other regions.

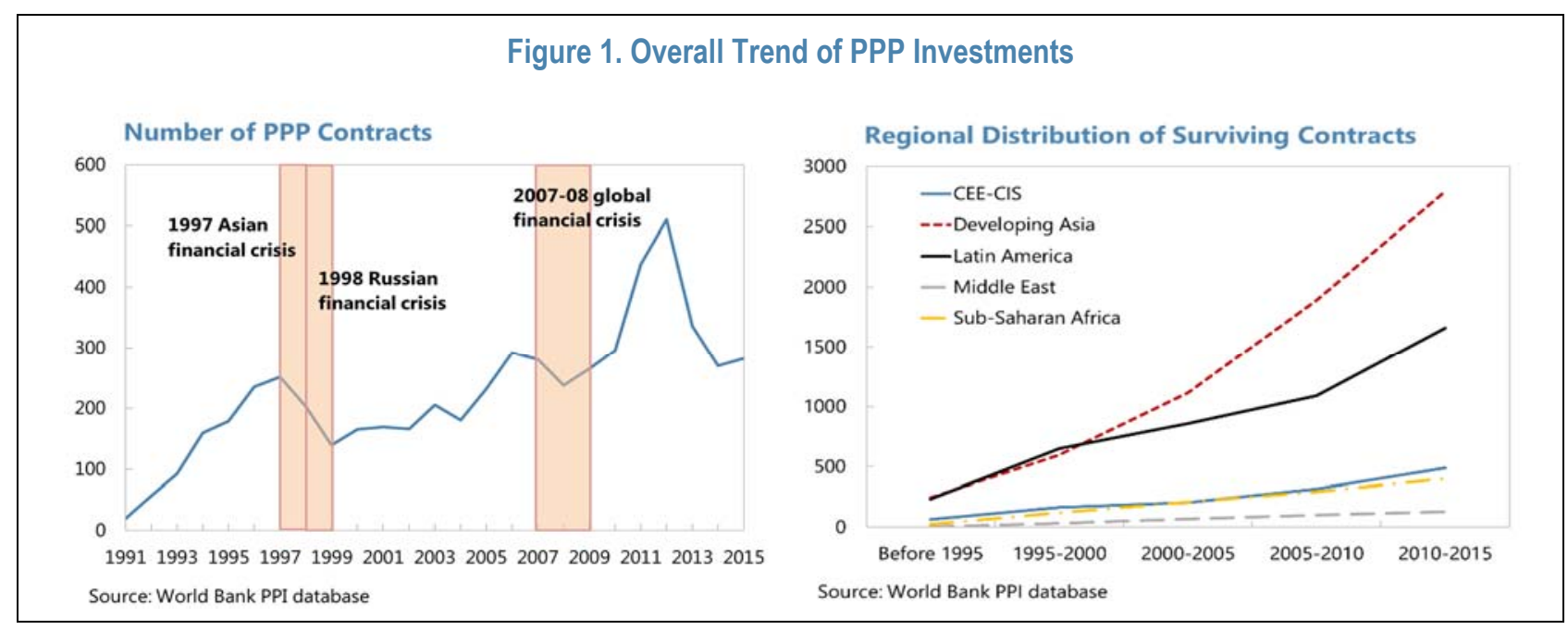

While the dispute risk peaked in the late 1990s to the early 2000s in developing Asia and LAC, it continued to rise in sub-Saharan Africa (SSA) where more contracts started to be signed (Figure 2). The dispute is more common in developing Asia, the Central and Eastern Europe \& the Commonwealth Independent States (CEE-CIS) and LAC, particularly in the upper-MICs.

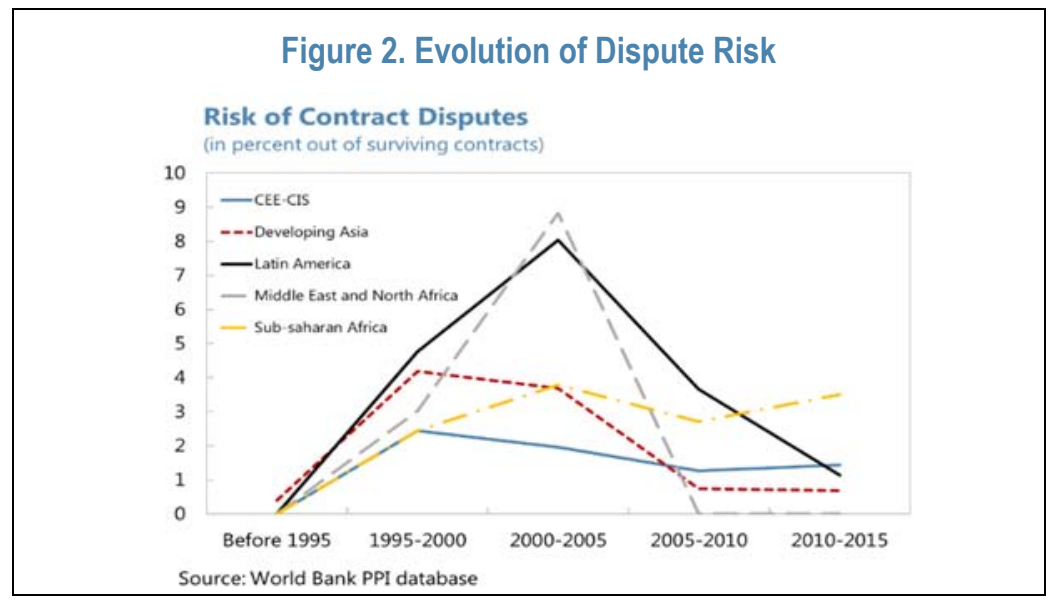




\section{B. Country-level Determinants of Contractual Disputes}

Appendix Figure A1 shows that PPPs (a measure of a government's past experiences in PPP schemes for infrastructure financing) and observed disputes tend to cluster in particular regions. One explanation of this cluster is that disputes are more common in countries vulnerable to financial crises. Dispute risk also tends to rise when an economy is hit by external shocks (such as commodity price fluctuations, natural disasters, and adverse shocks in growth and inflation) (Nose 2014). Another determinant of disputes relates to political regime change. Another explanation is institutional. Previous literature found that countries with authoritarian political regimes and poor economic and political institutions are more likely to initiate disputes (Acemoglu and Robinson, 2005; Eden, Kraay and Qian, 2012). Such findings are consistent with the patterns found in pre-claim data on breach of contract that were collected by World Bank's political risk insurance agency (MIGA). In many cases, economic crisis and a political regime change exposed PPP projects to financial stress or inconsistent policy (or both), leading to the renegotiations of contract.

\section{Contract Design and Fiscal Institutions}

In many PPP arrangements, governments offer guarantees, direct subsidies, or the Viability Gap Funds (VGFs) to support private participation in infrastructure (see Engel, Fischer, and Galetovic (2014) for the example of VGFs in India). ${ }^{4}$ While more private investors had sought for the supports from multilateral financial institutions (MFIs) in the early 1990s, the provisions of guarantees and direct subsidy have recently become important risk mitigation instruments for PPPs (Figure 3). In regional context, PPP contracts that received government guarantees and direct subsidies were concentrated in developing Asia and LAC (Figure 4). In both regions, concessions were also common. In SSA countries, guaranteed contracts have gradually increased but are still rare, and concessions and MFI-supported projects are more common. The recent increase in government involvements in PPPs could elevate the fiscal risk as more guarantees and subsidies are provided, especially if they are granted to pursue projects which are not always financially viable.

Indeed, PPPs were often motivated by country's fiscal constraints on borrowing and taxation that limited the government's financial ability to undertake public investments. PPPs are often used to circumvent budget constraints and to postpone recording the fiscal costs of investments rather than for efficiency reasons. In many countries, PPPs have not always performed better than public procurement as they have functioned as ad-hoc, off-budget arrangements without robust process for risk assessments. The success of PPPs depends on the effective procurement decisions, the economic and financial feasibility, and their efficient management and oversight under strong fiscal and legal institutions (Sabol and Puentes,

\footnotetext{
${ }^{4}$ Government guarantee takes different forms such as the minimum payment guarantee for covering the demand risk, the debt guarantee for covering the insolvency risk, the revenue guarantee for securing minimum revenues for private parties, and the exchange rate guarantee for covering the currency risk (World Bank, 2014b).

${ }^{5}$ Direct subsidies are payment commitment, such as a regular subsidy over the life-cycle of the project (called "availability payments") and a capital subsidy for covering initial construction cost (World Bank 2014b).
} 
2014). It also requires transparent disclosure of fiscal risk in the medium-term budgetary frameworks to monitor and manage contingent liabilities.

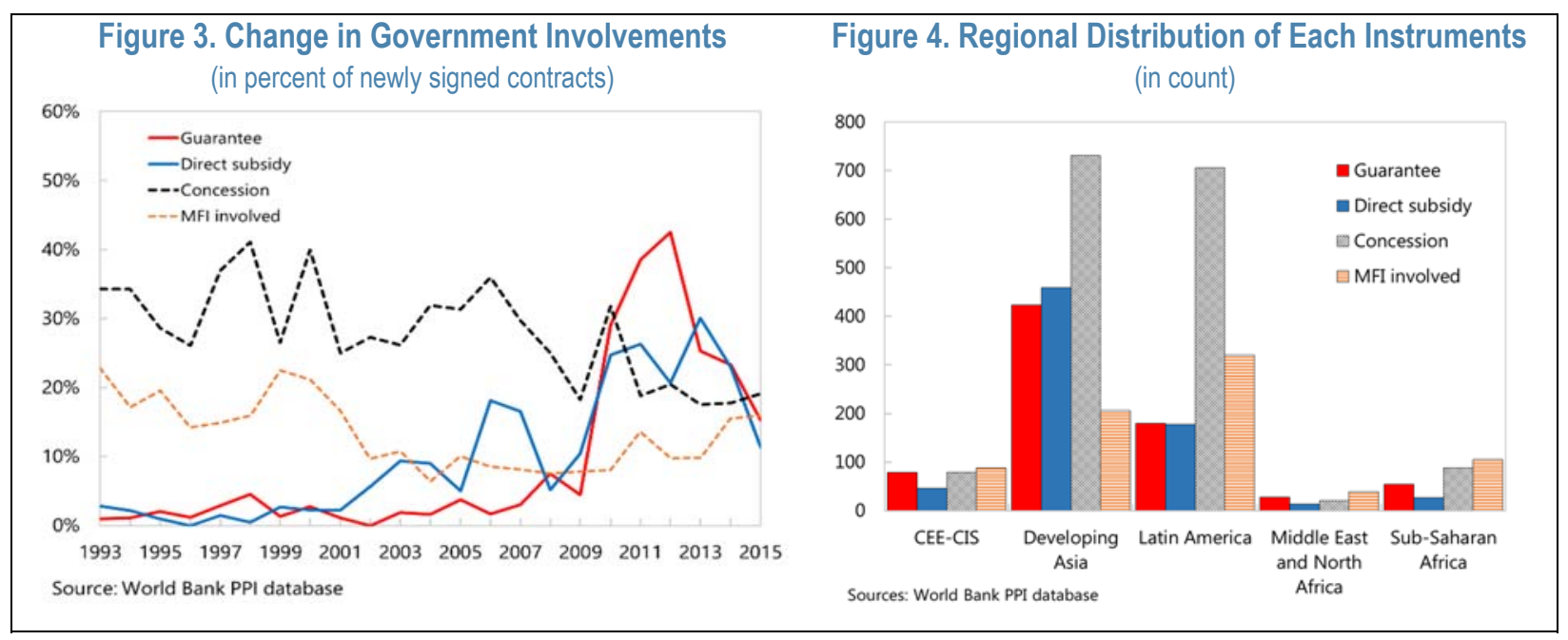

\section{THEORETICAL FrAMEWORK}

This section establishes a model to analyze how fiscal institutions - PIM quality and budget transparency-affect the survival of PPPs through government's procurement and investment decisions, and firm's participation in the contract.

\section{A. Procurement}

A government decides whether to use public procurement or PPPs based on its cost-benefit calculation and project profitability. With public procurement, the government allocates budget to make public investment $z$ which yields project returns $W_{A}$. With PPPs, the government sets up a private company - special purpose vehicle (SPV) - and engages with the SPV to develop, operate, and maintain the infrastructure. The SPV invests $k$, complementing public investments, and the return $\pi$ is linked to service outcomes and performance of the asset $W_{B}$. The SPV's return depends on expected demand for services $q$, project financing cost $r$, and operational costs $c_{1}$ for SPV. PPPs are often procured through a non-competitive process (e.g., unsolicited proposals) in the pre-matured PPP markets. PPP project could thus be inefficient, if politically motivated, and creates short-term rents $R$.

$$
\begin{gathered}
W_{A}=f(z) \\
W_{B}=f(k, z)+E \pi\left(q, r, c_{1}\right)-\chi_{1} R
\end{gathered}
$$

Higher PPP regulation and operational quality $\chi_{1} \in[0,1]$ limit politician's rent-seeking activities. The procurement selection is determined by the majority voting under citizencandidate model (Osborne and Slivinski, 1996; Besley and Coate, 1997). Voters are assumed to have policy bias $\sigma^{i}$ to PPPs which is uniformly distributed: $\sigma^{i} \sim U\left[-\frac{1}{2 b}, \frac{1}{2 b}\right]$. PPPs will be 
selected when it attracts majority voting: $\operatorname{Pr}\left(W_{A}<W_{B}+\sigma^{i}\right)>1 / 2$. This results in the condition below:

$$
\chi_{1}<\frac{f(k, z)-f(z)+E \pi\left(q, r, c_{1}\right)}{R}
$$

This condition implies that PPPs are chosen because of its higher efficiency gain than public procurement $(f(k, z) \gg f(z))$; or, regardless of project's feasibility, for the adverse selection caused by (i) overestimation of project return of PPPs $E \pi$ ex-ante ("optimism bias" (Flyvbjerg, 2009)) and (ii) rent-seeking by politicians, both due to weak PIM quality.

\section{B. Investment Decision}

When Eq. (1) is satisfied, the government pursues a PPP project under the build-operatetransfer (BOT) contract. The payment scheme can be: (i) government-pay (government provides a recurring subsidy (called availability payments) $\bar{\alpha}$ to firm, and firm invests in project) or (ii) user-pay (firm collects user-fees, and makes capital and operational investments). Government makes take-it-or-leave-it offer to the firm with contractual term: $A=(p, \bar{\alpha}, \mu)$ where $p$ is user fee and $\bar{\alpha}$ is availability payments. $\mu$ takes zero for the user-pay and one for the government-pay scheme. The asset will return to government when the contract terminates at time $\bar{t}$.

Government decides the optimal commitment on PPPs which maximizes the present value of output under the following budget constraint:

$$
\begin{gathered}
\max _{\{z\}} E_{t} \beta^{t} \sum_{t=0}^{\bar{t}} f\left(k_{t}, z_{t}\right) \\
\text { s.t. } \quad-T_{t}+i_{t}+c_{2} z_{t}+\mu \bar{\alpha}+\chi_{2} p\left(\underline{q}-q_{t}\right) z_{t} \leq L
\end{gathered}
$$

where $T$ is lump-sum tax revenues, $i_{t}=\left[z_{t+1}-(1-\delta) z_{t}\right]$ is infrastructure investment, and $c_{2}$ is operational cost for the government to maintain the infrastructure capital. $p q$ is userfees where $q$ is stochastic demand for public services: $q_{t}=\rho q_{t-1}+\varepsilon_{t}$ and $\varepsilon_{t} \sim N\left(0, \sigma^{2}\right)$. The government may offer direct subsidy $\bar{\alpha}$ (if $\mu=1$ ), and revenue guarantee $p(q-q) z_{t}$ to ensure the minimum user-fee revenues $p q z_{t}$ to the firm. The project yields financial loss if the demand for public services decreases below the break-even level. Fiscal sustainability requires the fiscal deficit to be below the fiscal limit $L$.

The budget constraint incorporates transparency in reporting the fiscal risk of guarantees. The budget transparency is higher as the value of $\chi_{2}$ approaches one, while close to zero if a contingent liability is hidden by undertaking the PPP off-budget.

Assuming the Cobb-Douglas production function $f\left(k_{t}, z_{t}\right)=k_{t}^{\varphi} z_{t}^{\gamma}$, the return to private investment $\varphi$ increases as service quality improves. The firm chooses the optimal level of private investment $k^{*}$ that maximizes the project return: $k_{t}^{*}=\arg \max \left(k_{t}^{\varphi} z_{t}^{\gamma}+\mu \bar{\alpha}-r k_{t}-\right.$ 
$c_{1} k_{t}$ ) where last two terms are the firm's financing and operational cost every period. Given $k^{*}$, the dynamic optimization solves the optimal level of public investment $z^{*}$ as follows:

$$
z_{t}^{*}=\left[\frac{\left(\frac{\gamma}{1-\varphi}\right)\left(\frac{\varphi}{r+c_{1}}\right)^{\frac{\varphi}{1-\varphi}}}{\beta\left(c_{2}+\chi_{2} p\left(\underline{q}-q_{t}\right)-(1-\delta) E_{t} \lambda_{t+1}\right.}\right]^{\frac{1-\varphi}{1-\gamma-\varphi}}
$$

where $E_{t} \lambda_{t+1}$ is the dynamic Lagrange multiplier which gets lower as lump-sum tax increases $\left(\frac{\partial E_{t} \lambda_{t+1}}{\partial T_{t}}<0\right)$ and higher as fiscal costs (direct subsidy and fiscal risk of guarantees) increase $\left(\frac{\partial E_{t} \lambda_{t+1}}{\partial \bar{\alpha}}>0, \frac{\partial E_{t} \lambda_{t+1}}{\partial \chi_{2}}>0\right)$ (see appendix E).

From Eq. (3), $\frac{\partial z_{t}^{*}}{\partial \chi_{2}}<0$, implying that the optimal level of PPP investment declines as budget transparency improves. In other words, the lack of budget transparency leads to overcommitment on PPPs. If combined with the adverse selection of riskier PPP investments, this leads to over-commitment on infeasible PPPs which likely trigger guarantees (Maskin and Tirole, 2008; Milesi-Ferretti, 2003).

\section{Conditions for Outbreak of Disputes}

For both the government-pay and the user-pay schemes, the model illustrates the conditions under which disputes are initiated either by the firm or the government.

\section{Firm-led disputes}

- $\quad$ Under the government-pay scheme:

The government-pay contract $(\mu=1)$ is financed by government's subsidy $\bar{\alpha}$. The firm refuses to participate in the contract if the participation constraint is violated $\left(\Pi_{t}<0\right)$ where $\Pi_{t}=\bar{\alpha}-\left(r+c_{1}\right) k_{t}^{*}$. In this case, the firm initiates disputes when subsidy is insufficient to recover financing and operational costs: $\bar{\alpha}<\left(r+c_{1}\right) k_{t}^{*}$ for $\forall t$.

\section{- Under the user-pay scheme:}

The use-pay contract $(\mu=0)$ creates financial loss if user-fee revenues are lower than the minimum threshold. The loss occurs with probability $F(\epsilon)=\operatorname{Pr}\left(q_{t}<\underline{q}\right)=\Phi\left(\underline{q}-\rho q_{t-1}\right)$ where $\Phi(\cdot)$ is the cumulative distribution function. Firm's participation constraint is violated if $\Pi_{t}^{\prime}=p[F(\epsilon) \underline{q}+(1-F(\epsilon)) q]-\left(r+c_{1}\right) k_{t}^{*}<0$ for $\forall t$.

When PIM quality is weak, the break-even public service demand $\underline{q}$ would be over-estimated ex-ante, increasing the likelihood of incurring financial loss $F(\epsilon)$. 


\section{Government-led disputes}

- $\quad$ Under the government-pay scheme:

The government decides whether to continue PPPs by comparing welfare levels when the project completes $\left(W_{H}\right)$ vs. being terminated $\left(W_{N H}\right)$. Successful PPP projects continue until period $\bar{t}$ and yields welfare $W_{H}$, which is the sum of net present value (NPV) of expected outputs and the SPV's profit, and the residual value of the asset $I$ at the end of the contract.

$$
W_{H}=E_{t} \beta^{t} \sum_{t=0}^{\bar{t}}\left[k_{t}^{* \varphi} z_{t}^{* \gamma}+\Pi_{t}\right]+\beta^{\bar{t}} I
$$

After the project starts, the government may breach the contract at period $\tau$ but pay the reputation cost $H$, and continue the project under public procurement afterwards. In this case, the welfare function after the period $\tau$ becomes:

$$
W_{N H \mid t \geq \tau}=\beta^{t} \sum_{t=\tau}^{\bar{t}}\left[{\widetilde{z_{t}}}^{* \gamma}-c_{2}{\widetilde{z_{t}}}^{*}\right]+\beta^{\tau} I-H(\sigma)
$$

where $\tilde{z}^{*}$ is the optimal public capital under traditional public procurement. The reputation cost would be higher when the government faces stronger political constraint $\sigma$ with $H^{\prime}(\sigma)>0$. Contract will be terminated if:

$$
\begin{gathered}
W_{N H}-W_{H} \geq 0 \\
\Leftrightarrow \beta^{t} \sum_{t=\tau}^{\bar{t}}\left\{\left[E_{t}\left(k_{t}^{* \varphi} z_{t}^{* \gamma}\right)-{\widetilde{z_{t}}}^{* \gamma}\right]+\left[\Pi_{t}-c_{2}{\widetilde{z_{t}}}^{*}\right]\right\} \leq\left(\beta^{\tau}-\beta^{\bar{t}}\right) I-H(\sigma)
\end{gathered}
$$

The first square bracket of Eq. (4) captures the efficiency gains of PPP compared to public procurement, and the second square bracket captures the value for money. Both terms get larger when PPPs become more cost-effective. The government-led dispute occurs when the sum of these two terms get smaller than the right-hand side (i.e., the residual value of the asset net of reputation cost).

\section{- Under the user-pay scheme:}

Similarly, the welfare $W_{H}^{\prime}$ is defined as follows for the user-pay scheme:

$$
W_{H}^{\prime}=E_{t} \beta^{t} \sum_{t=0}^{\bar{t}}\left[k_{t}^{* \varphi} z_{t}^{* \gamma}+\Pi_{t}^{\prime}-\chi_{2} p\left(\underline{q}-q_{t}\right) z_{t}^{*}\right]+\beta^{\bar{t}} I
$$

The third time captures the fiscal risk for the government. As $W_{N H}$ remains the same, the condition for contract breach is expressed as follows:

$$
W_{N H}-W_{H}^{\prime} \geq 0
$$


$\Leftrightarrow \beta^{t} \sum_{t=\tau}^{\bar{t}}\left\{\left[E_{t}\left(k_{t}^{* \varphi} z_{t}^{* \gamma}\right)-{\widetilde{z_{t}}}^{* \gamma}\right]+\left[\Pi_{t}^{\prime}-\chi_{2} p\left(\underline{q}-q_{t}\right) z_{t}^{*}-c_{2}{\widetilde{z_{t}}}^{*}\right]\right\} \leq\left(\beta^{\tau}-\beta^{\bar{t}}\right) I-H(\sigma)$

Eq. (5) implies that the accumulation of PPP's contingent liabilities could induce the government to initiate disputes.

From the theoretical model, testable predications can be obtained as below:

- Hypothesis 1 (Adverse selection and PIM quality): Weaker PIM quality $\chi_{1}$ could result in the adverse selection of high risk projects.

- Hypothesis 2 (Budget transparency): Lack of budget transparency $\chi_{2}$ in reporting contingent liabilities from guaranteed debt leads to over-commitment on PPPs.

- Hypothesis 3 (Effect of guarantee): The provision of guarantees encourages firm's participation in PPPs, while increasing the government-led disputes for higher fiscal risk and insufficient returns to recover project costs.

- Hypothesis 4 (Reputation costs): The likelihood of reneging contract is lower with stronger political constraint: $\frac{\partial \Omega}{\partial H(\sigma)}>0 .{ }^{6}$ ("sovereign theft" by Tomz and Wright (2010))

\section{Data AND Methodology}

\section{A. Data and Sample}

Contractual dispute data come from the World Bank's Private Participation in Infrastructure (PPI) Database. Additional data were collected from various public sources (such as Factiva, websites of multilateral agencies and sponsors) and information from project entities. While Guasch, Laffont, and Straub (2007) focused on concessions in Latin America, it covers both greenfield contracts, represented by BOT, and brownfield concessions for 113 emerging and developing countries (see Table A1 for country list and Table A2 for the summary statistics). The data include about 6,000 PPP contracts signed between 1984 and 2015.

The data examine the nature of disputes in detail, and distinguish whether they are triggered by the government or private investors. Contracts are classified as "disputed" if they were distressed, renegotiated or cancelled due to conflicts between the government and private parties. Disputes triggered by sovereign risk including economic crisis (financial crisis, sharp currency devaluations) and political risk (nationalization, expropriation, policy changes in tariff setting) are classified as "government-led", while they are "firm-led" disputes if triggered by sponsor's insolvency and technical problems. Even though contracts experienced distress, they are classified as "non-disputed" if the renegotiations were caused

\footnotetext{
${ }^{6}$ The political constraint will be more binding in countries that receive supports from MFIs (Jensen et al, 2017) and in democratic and stable governments (Arezki and Gylfason, 2011; Besley and Ghatak, 2010).
} 
by the sponsor's unilateral actions (e.g., change in business strategy) or uninsurable external events beyond the control of the parties (such as war and civil conflict).

\section{B. Hazard Estimation}

The reduced-form approach (the hazard model) is used to test the hypotheses derived in section III. It estimates the probability of disputes conditional on the duration of contract $A_{i}$, defined as the number of years a project survives before it ends due to contract breach or termination. The data are right-censored if the project is still ongoing in 2015. The observed duration is $A_{i}=\min \left(A_{i}^{*}, c\right)$ where $c$ is 2015 for all censored contracts. Assuming the density of $A_{i}$ follows the Weibull distribution, ${ }^{7}$ the hazard function $\lambda$ can be estimated parametrically as: $\lambda\left(A_{i} ; x_{i c r}\right)=\exp \left(x_{i c r}^{\prime} \beta\right) \alpha A_{i}^{\alpha-1}$ where $\alpha$ is the measure of duration dependence. Standard errors are clustered over industry and contract year levels.

The hazard regression evaluates fiscal commitments, and contract- and country-level characteristics in determining dispute risk. In the above hazard function, $x_{i c r}=$ $\left[X_{1, i} ; X_{2, c} ; D_{j r}\right]$ are covariates for contract $i$ in sector $j$, country $c$ and region $r . X_{1, i}$ is contract-level characteristics such as financial arrangements with MFIs, the government's provision of guarantees and direct subsidies, and concession agreement. $X_{2, c}$ is the countrylevel variables on the short-term macroeconomic fluctuations (average real GDP growth and inflation during the contractual period) and the quality of political institutions (democratic regime and the duration of national leaders). ${ }^{8}$ Dummies for regional and sectoral affiliations $D_{j r}$ are also included to account for the regional and sectoral clustering of dispute events as shown in section II.

\section{Bias Adjustment using the Propensity Score Matching (PSM)}

The selection of contract type would depend on the characteristics of the government and private firms, which biases the estimates of contract-level variables. Previous literature applied the PSM (Austin, 2013; Gayat et al, 2012) or instrumental variable (Guasch, Laffont, and Straub, 2007) to minimize the selection bias. Given the non-linearity of the hazard model and the absence of valid instruments, this paper applies the PSM where the hazard estimates are adjusted by applying the inverse probability of treatment weighting (IPTW). The PSMIPTW method offers the most parsimonious specification with least mean squared error when estimating the hazard model (Austin 2012). The selection on unobservable could still exist for unobserved omitted factors (i.e., investor's strategic skills in drafting contracts) (Guasch, Laffont, and Straub, 2007), although bias would be minimized by including comprehensive set of country- and investor-level covariates to match the characteristics between different contract types.

\footnotetext{
${ }^{7}$ Among parametric models (such as exponential, loglogistic and lognormal distributions), the Weibull distribution is preferred as it gives the largest log likelihood and the smallest Akaike information criterion.

${ }^{8}$ Negative (positive) Polity IV score means autocratic (democratic) regimes following Besley and Kudamatsu (2008). This paper assigns a score from 0-20 (where 0 means the most autocratic and 20 is the most democratic regime).
} 


\section{EMPIRICAL RESULTS}

Following section III, this section first tests whether government's fiscal conditions and budget transparency, controlling for economic and political variables, determine governments' decision to offer guarantees vs. other contract types as predicted in the hypothesis 2. The subsection V.B applies the PSM-IPTW method to the hazard model and tests the effect of guarantees on the probability of disputes (hypothesis 3 ) and whether reputation cost binds government's incentive to initiate disputes (hypothesis 4). The subsection V.C offers the robustness checks. Finally, the subsection V.D examines negative adverse selection and contingent liability effects in triggering disputes due to weak PIM quality and low budget transparency as predicted in hypotheses 1 and 2 .

\section{A. Determinants of Contract Selection}

As the first stage of the hazard regression, the probit model estimates the probability of drafting a contract with (i) MFI support (loans, equity investments, or guarantees), (ii) guarantees, (iii) direct subsidies, and (iv) concession agreement. It includes country-level variables (regulatory quality and bureaucratic efficiency as measured by the World Bank's governance indicator, fiscal and public debt situations, and commodity exporter status), contract-level variable (investment size), and investor's risk attitude (captured by a dummy whether the sponsor originates local or foreign). Regional and sector dummies are also controlled. Main results in Table 1 are summarized as follows:

- Gross financing needs (GFN) (in percent of GDP) is positively signed for guarantees, implying that government with large GFN tends to make suboptimal risk commitments in PPPs with guarantees to avoid immediate payments in the short-term. In column 3 , the public debt is interacted with Wang et al. (2015)'s budget transparency index in terms of the coverage of fiscal reporting on stock (in column 3; see more details in section V.D). The positive coefficients of public debt variable and the negative interaction term with the budget transparency index indicate that indebted governments tend to make risky commitments with guarantees, but such suboptimal risk commitment decreases in countries with higher budget transparency. The GFN variable is negatively signed for direct subsidies. As the fiscal financing requirements increase, government has less fiscal space to subsidize the project while relying more on guarantees and concessions to implement the project.

- The contract selection also hinges on the quality of institutions. The government with better regulatory environment (central regulatory body in supervising the PPPs) can formulate large-scale PPP projects with MFI supports. On the other hand, when the bureaucracy process is more efficient, government may well improve the quality of existing infrastructure under concessions. Higher bureaucratic efficiency is also associated with a lower probability for government to offer guarantees and makes private financing feasible with direct subsidies. 
- Local investor's participation in the contract increases the likelihood that projects receive direct subsidies, ${ }^{9}$ reflecting private party's strategic decision in involving local investors in the government-funded projects. Likewise, for concessions, government prefers to select private parties with local investor's participation to offer business opportunities to local partners, to utilize their local knowledge and network, or to maintain the government's control over the asset.

- PPP contracts signed in commodity exporting countries tend to receive more guarantees and direct subsidies than commodity importers.

\begin{tabular}{|c|c|c|c|c|c|}
\hline & $(1)$ & (2) & (3) & (4) & (5) \\
\hline & MFI supports & \multicolumn{2}{|c|}{ Guarantees } & Direct subsidy & Concession \\
\hline \multirow[t]{2}{*}{ Ln(investment size) } & 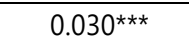 & 0.002 & 0.003 & 0.003 & -0.002 \\
\hline & {$[0.002]$} & {$[0.002]$} & {$[0.002]$} & {$[0.002]$} & {$[0.003]$} \\
\hline \multirow[t]{2}{*}{ Ln(GDP per capita in 2000) } & -0.141 & $-0.395^{\star *}$ & -0.289 & $0.635^{\star * *}$ & -0.294 \\
\hline & {$[0.171]$} & [0.192] & [0.194] & {$[0.236]$} & {$[0.201]$} \\
\hline \multirow[t]{2}{*}{ Ln(GDP per capita in 2000) squared } & 0.005 & $0.027^{* *}$ & 0.019 & $-0.045^{\star * *}$ & 0.014 \\
\hline & {$[0.010]$} & {$[0.012]$} & {$[0.012]$} & {$[0.014]$} & {$[0.012]$} \\
\hline \multirow[t]{2}{*}{$\operatorname{Ln}(G F N / G D P)$} & $0.055^{\star * *}$ & $0.052^{* * *}$ & $0.058^{\star * *}$ & $-0.084^{\star * *}$ & $0.059^{* * *}$ \\
\hline & {$[0.013]$} & {$[0.014]$} & {$[0.014]$} & {$[0.018]$} & {$[0.018]$} \\
\hline \multirow[t]{2}{*}{ Ln(public debt/GDP) } & -0.015 & -0.017 & $0.036^{* *}$ & $0.051^{* * *}$ & $0.031^{* *}$ \\
\hline & {$[0.011]$} & {$[0.013]$} & {$[0.017]$} & {$[0.014]$} & {$[0.013]$} \\
\hline \multirow[t]{2}{*}{ Budget transparency index (stock) } & & -0.003 & $0.397^{* * *}$ & $0.053^{* * *}$ & 0.001 \\
\hline & & {$[0.010]$} & [0.101] & {$[0.011]$} & {$[0.011]$} \\
\hline \multirow[t]{2}{*}{--- x Ln(public debt/GDP) } & & & $-0.104^{* * *}$ & & \\
\hline & & & {$[0.026]$} & & \\
\hline \multirow[t]{2}{*}{ Regulatory quality } & $0.076^{\star * *}$ & $0.068^{* * *}$ & 0.031 & $-0.132^{* * *}$ & $-0.076^{* * *}$ \\
\hline & {$[0.020]$} & {$[0.020]$} & {$[0.022]$} & {$[0.025]$} & [0.024] \\
\hline \multirow[t]{2}{*}{ Bureaucratic efficiency } & $-0.119^{\star \star *}$ & $-0.165^{\star \star \star}$ & $-0.120^{\star \star *}$ & $0.261^{* \star *}$ & $0.064^{\star *}$ \\
\hline & {$[0.025]$} & [0.023] & {$[0.026]$} & [0.032] & {$[0.030]$} \\
\hline \multirow[t]{2}{*}{ Commodity exporter } & -0.006 & $0.037^{* \star *}$ & $0.041^{* * *}$ & $0.065^{\star \star *}$ & -0.011 \\
\hline & {$[0.011]$} & {$[0.012]$} & {$[0.012]$} & {$[0.012]$} & {$[0.012]$} \\
\hline \multirow[t]{2}{*}{ Sponsor with same nationality } & $-0.043^{* * *}$ & 0.001 & 0.003 & $0.049 * * *$ & $0.039 * * *$ \\
\hline & {$[0.009]$} & {$[0.009]$} & {$[0.009]$} & {$[0.010]$} & {$[0.011]$} \\
\hline \multirow[t]{2}{*}{ Dummy: post-2000 } & $-0.062^{\star \star \star}$ & $0.176^{\star \star \star}$ & $0.171^{* * *}$ & $0.191^{\star \star *}$ & $-0.051^{* * *}$ \\
\hline & {$[0.010]$} & {$[0.017]$} & {$[0.017]$} & {$[0.017]$} & [0.012] \\
\hline Observations & 5,877 & 5,877 & 5,877 & 5,877 & 5,877 \\
\hline Log-likelihood value & $-1,873.2$ & $-1,807.5$ & -1799.8 & $-1,804.5$ & $-2,243.4$ \\
\hline Pseudo R-squared & 0.142 & 0.195 & 0.199 & 0.174 & 0.348 \\
\hline Sector \& region dummies & Y & Y & Y & Y & Y \\
\hline Average(dependent var) & 0.124 & 0.128 & 0.128 & 0.123 & 0.272 \\
\hline
\end{tabular}

\footnotetext{
${ }^{9}$ This is typically the case in developing Asia and BRICs. More than 60 percent of the contracts involve local investors in countries such as Turkey, Colombia, Argentina, and Nigeria.
} 


\section{B. Hazard Regression}

In Table 2 below, baseline hazard estimates show that contract duration, contract characteristics and country-level variable affect the hazard rate of PPP in expected ways:

- As reported at the bottom of Table 2, duration dependence parameter is always greater than one $(\alpha>1)$, confirming the positive duration dependence. This implies that the probability of disputes increases as the contract matures and the government would have stronger incentives to renegotiate contract, as predicted by the obsolescing bargain hypothesis (Woodhouse, 2006). ${ }^{10}$

- The investment size is positively signed and significant, indicating that larger PPP projects face higher dispute risk. A dummy of MFI's supports is negatively signed, implying that involving multilateral institutions, which have more experiences with PPPs than other private sponsors or lenders, could mitigate dispute risk for foreign investors. The effect is however not significant on average.

- The country-level variables show broadly consistent results as found in the literature. The negative coefficients of democratic regime (column 1) and the duration of leaders in democratic countries (column 2) suggest that PPP contracts are more likely to survive in democratic countries with stable political regime. Real GDP growth is negatively signed while CPI inflation is positive, showing that improvements in macroeconomic conditions during the contract would create buffers to reduce the dispute risk.

- Learning from past experiences is also an important factor in implementing PPPs. From the IMF's investment and capital stock dataset, the value of the stock of PPPs (in percent of GDP) is added in column 4. ${ }^{11}$ The coefficient is negative, although not statistically significant, suggesting that PPP contracts tend to survive longer in countries with more PPP experiences.

The columns 5-7 apply the PSM-IPTW method to distinguish contracts with guarantees (column 5), direct subsidies (column 6), and concessions (column 7). In the PSM-IPTW regression, the first-stage regression in Table 1 is used to estimate the propensity score to match the characteristics of the contract between treated (those with fiscal commitments) and control group. The technical appendix table A3 shows the balancing test which supports the validity of the PSM in matching contract characteristics of two groups.

The result shows that guaranteed contracts face significantly higher hazard rate than nonguaranteed contracts (equivalent to the hazard ratio of 4.3) (column 5). Higher hazard rate results from the amplification of fiscal risks due to inadequate market test on projects'

\footnotetext{
${ }^{10}$ Woodhouse (2006) discusses the obsolescing bargaining power of foreign investors and describes the situation where an investor loses the bargaining power as the contract ages since exiting from a committed investment becomes costly due to high sunk costs, providing host governments with stronger leverage to break contracts.

11 The dataset is available at http://www.imf.org/external/np/fad/publicinvestment/\#5.
} 
financial viability. The effect of direct subsidy is also positive but not statistically significant (column 6). Concessions tend to be riskier than greenfield investments as the demand risk is fully taken by private parties (column 7).

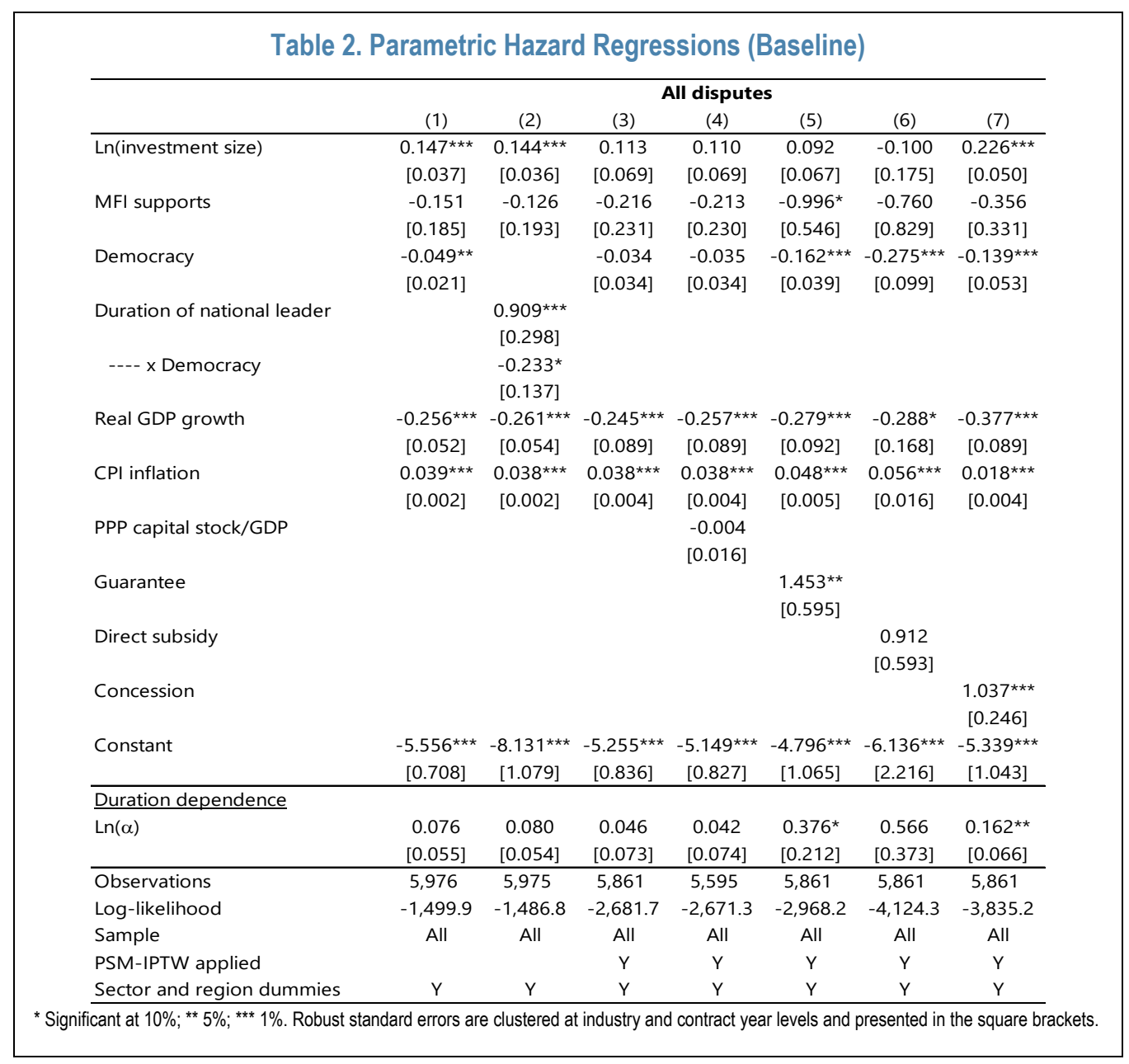

\section{Robustness Checks in Alternative Specifications}

Figure 5-1 compares the hazard ratio estimated under the baseline with results under alternative specifications: when (i) the sample is split by the maturity of PPP market (countries which have large representation (top 5 percent) in terms of the number of PPP contracts against less matured PPP countries), (ii) 1,954 contracts signed in LAC countries, one of the epicenters of disputes, are excluded, ${ }^{12}$ and (iii) the sample is restricted to contracts signed in SSA. Figure 5-2 restricts the sample to user-pay contracts, or dependent variable is replaced with the government-initiated dispute cases. ${ }^{13}$

\footnotetext{
${ }^{12}$ Matured market group includes top 7 countries in the appendix A (i.e., China, India, Brazil, Mexico, Chile, Argentina, and Turkey). Disputes in LAC region tended to be triggered by government's expropriatory actions which are different in nature compared with disputes in other regions (see Weems, P. and Salo, M. (2012) Mitigating Expropriation Risk of Natural Gas Projects, Energy Newsletter, July 2012).

${ }^{13}$ Data can distinguish dispute type between the government-led vs. firm-led cases only for contracts signed before 2012 , and thus the sample size declines to 4,500.
} 
The hazard ratios of guarantees and concessions remain above one and are significant in all specifications except the SSA sample (the upper panel of Figure 5-1). The hazard ratio of guarantee is significantly higher in matured PPP markets compared to less matured markets, and is slightly higher when LAC countries are excluded. In contrast, the hazard ratio of concession is significantly higher in less matured markets. In SSA countries, PPPs with guarantees are increasing but still not common (see Figure 4). The result suggests that guaranteed contracts face lower dispute risk while concessions are riskier in the SSA compared with the baseline, reflecting larger demand risk taken by private sector for business operations in SSA countries. The upper panel of Figure 5-2 shows that guaranteed contracts face slightly higher dispute risk when the sample is restricted to user-pay scheme, while the risk triples in case of the government-led disputes. This suggests that disputes for guaranteed contracts are mostly initiated by the government.

The lower panel in Figures 5-1 and 5-2 shows that the effects of MFI supports and democratic regime on the hazard ratios remain below one throughout all specifications, showing robust results in reducing disputes. The MFI support dummy mitigates the dispute risk in any sub-samples, but the effect is particularly large in matured PPP markets and when LAC countries are excluded. The negative effects also become significantly larger when the dispute type is restricted to the government-led disputes. This shows that the government-led dispute risk could be significantly lower when MFIs are involved due to higher reputation cost that the government must incur in breaching the contract. Democratic regime, as opposed to autocracy, could also significantly reduce the government-led disputes.

\section{Role of Public Financial Management}

Hypotheses 1 and 2 predict that stronger fiscal management capacity would increase the survival rate of contracts. To test this, a PIM quality measure is constructed from three difference data sources. The main data come from the EIU's Infrascope index, which is the weighted score of the quality of PPP regulations, the institutional framework, and the operational capacity in conducting PPPs. The Infrascope reports for Asia, CEE-CIS, LAC, and SSA regions currently cover 75 countries. The sample coverage is expanded by imputing missing observations using the IMF (2015)'s public investment management assessment (PIMA) index on PPPs and World Bank (2016)'s scores on PPP preparation, procurement, and contract management. The new index measures the PIM quality directly on PPPs (scaled from 0 (low) to 100 (high)), a more relevant measure than public investment management index (PIMI) (Dabla-Norris et al, 2012) in case of PPPs. ${ }^{14}$

\footnotetext{
14 The PIMA index rates the quality of PPP management for 25 countries, and the World Bank's index provides similar scores on PPP procurement for 82 countries. Both indices are highly correlated with the EIU's Infrascope index. As the Infrascope misses some countries which receive significant PPP investments, the estimates from the Tobit regression (which regresses the Infrascope index on the PIMA and the World Bank's index) are used to extrapolate data for those missing countries.
} 
Figure 5-1. Change in Hazard Ratio: by Country Groups

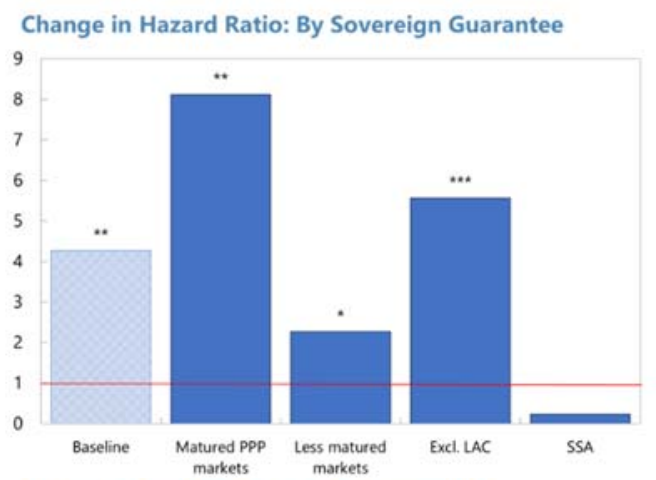

Change in Hazard Ratio: By MFI Supports

Change in Hazard Ratio: By Concessions
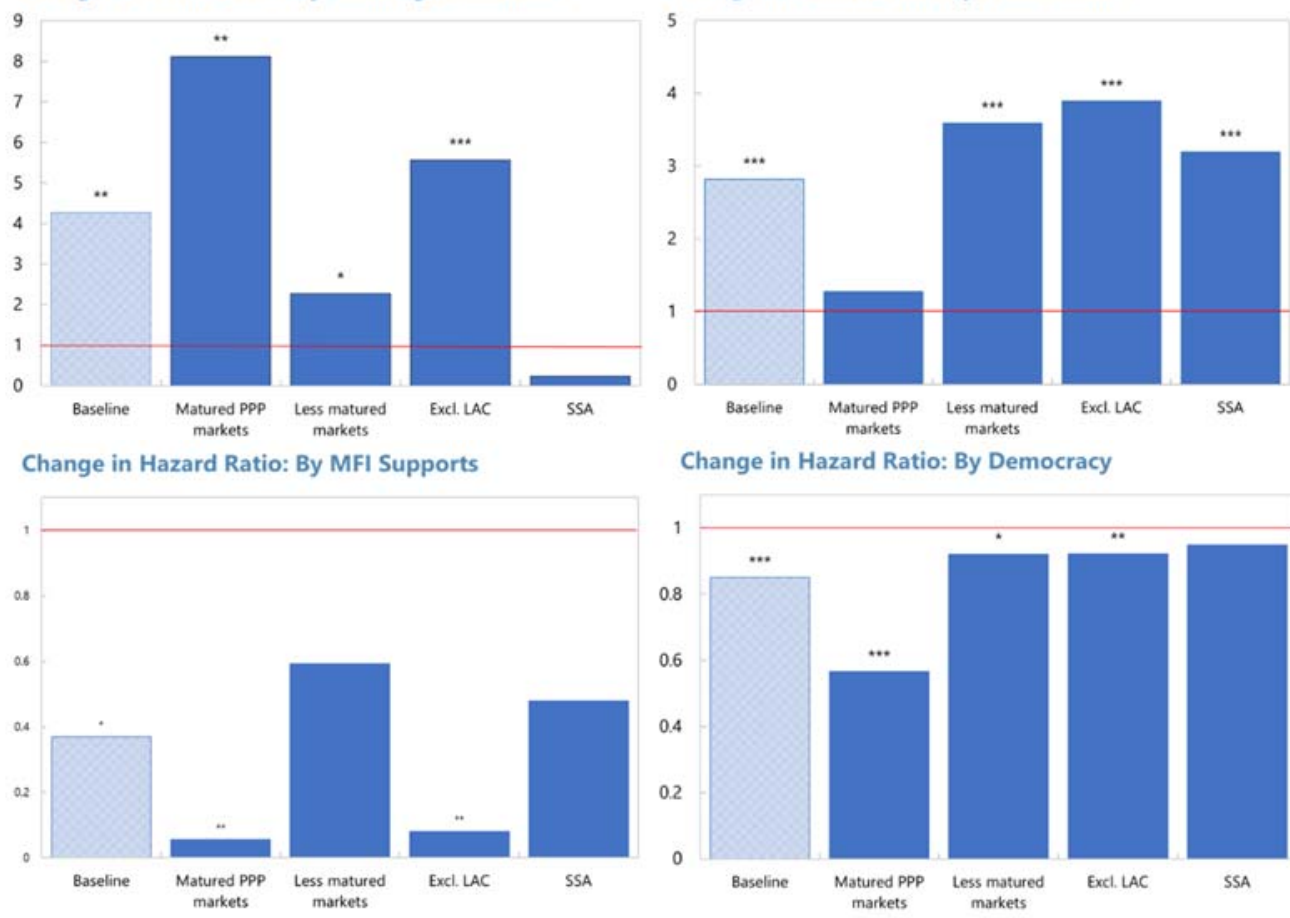

Change in Hazard Ratio: By Democracy

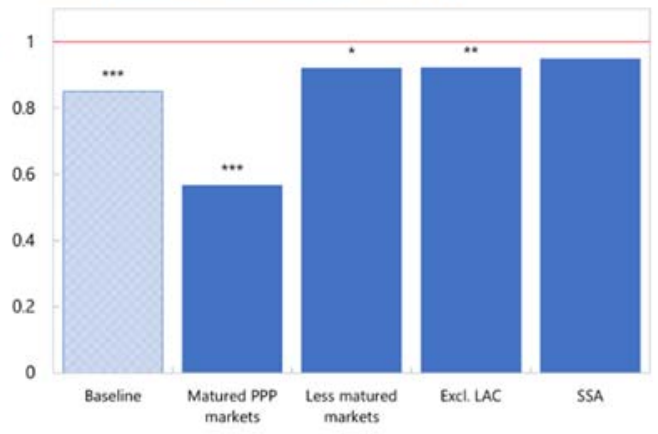

Figure 5-2. Change in Hazard Ratio: by Contract and Dispute Types
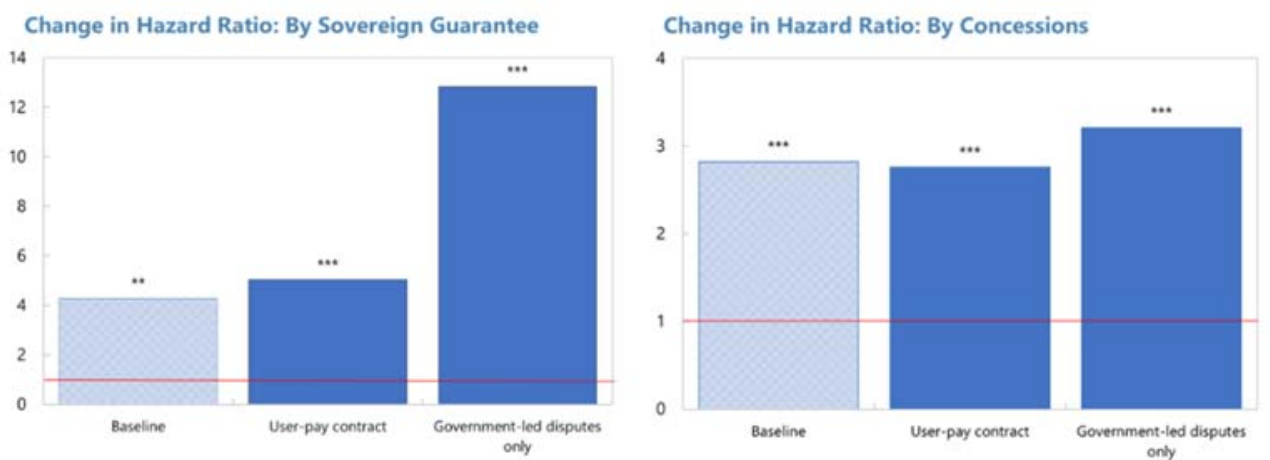

Change in Hazard Ratio: By MFI Supports

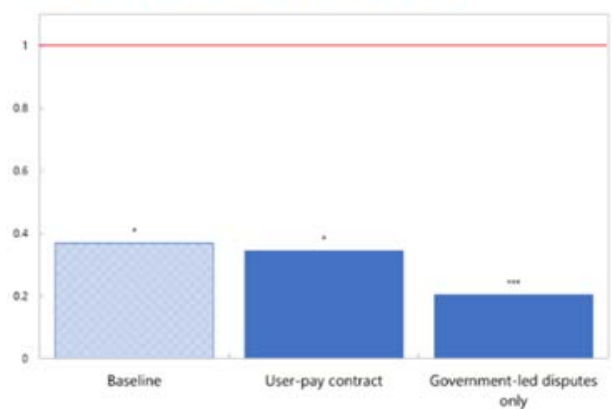

Change in Hazard Ratio: By Democracy

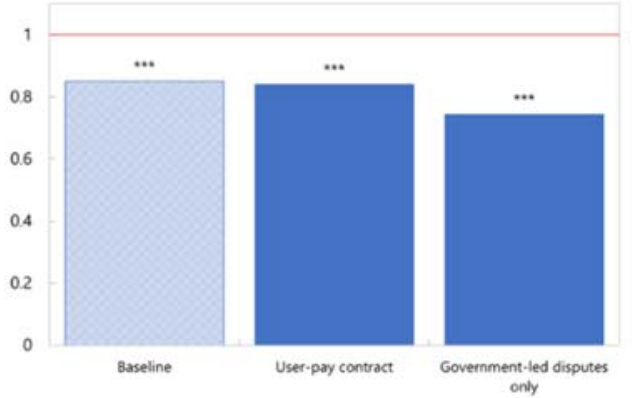

Source: World bank PPI database

* Significant at 10\%; ** $5 \%$; *** $1 \%$. PSM-IPTW regression is applied with region and sector dummies. Robust standard errors are clustered at industry and contract year levels. The first bar shows the hazard ratio of the baseline case using the whole sample in table 2 . The dependent variable is the hazard of all disputes except the last bar in Figure 5-2 which is only for the government-led dispute case. Hazard ratio of 1 (horizontal red line) means that the relative dispute risk is same between two types of contract. 
As shown in Figure 6, the PPP PIM quality index (y-axis) and country's budget transparency index (x-axis) are positively correlated. The left panel defines the budget transparency for the coverage of stock (i.e., reporting of liabilities, financial and nonfinancial assets in the government's balance sheet), while the right panel refers to the coverage of flows (i.e., government's operational statement). The positive correlation suggests that fiscally transparent countries tend to score higher on PPP's contract management. In regional perspective, the PIM quality shows large variance especially in Latin America. The mean comparison t-test shows that budget transparency, both in stock and flow, is significantly lower in LICs ( $\mathrm{p}$-value $=0.00)$.

Improvements in PIM quality and budget transparency would address the adverse selection and the accumulation of hidden debt respectively, contributing to the survival of PPPs. Table 3 presents the estimates of hazard regression with additional variables on a country's overall PPP management quality (columns 1-2), operational maturity in PPPs (columns 3-4), and budget transparency in reporting fiscal stocks (columns 5-6). ${ }^{15}$ Both PPP's PIM quality index and the budget transparency index are standardized around the mean.

Columns 1, 3 and 5 show that contracts that receive government guarantees face higher disputes risk, while higher PPP PIM quality contributes to significantly reduce disputes. In columns 2, 4, and 6, the sample is split into two groups: a group with above average scores on PIM quality or budget transparency vs. those below the average scores.

First, columns 2 and 4 show that the coefficient of guarantee dummy increases to 2.1 for lower PIM group, reflecting significant negative adverse selection effect of PPP contracts that increases disputes for low PIM group. ${ }^{16}$ Column 6 shows that the coefficient of guarantees rise to 1.9 for contracts signed in countries with non-transparent budget reporting system. This identifies pure contingent liability effect. The equality of coefficient $F$ test confirms significant differences in coefficient of guarantees between two groups categorized by the PIM quality and budget transparency. ${ }^{17}$

\footnotetext{
${ }^{15}$ Overall PPP quality measures the soundness of PPP regulations, PPP institutional framework, and operational maturity (e.g., project selection, risk assessments, and implementation of PPPs). The budget transparency index is the average scores on the transparency in reporting fiscal stocks and the fiscal institutional coverage (i.e., the disclosure of fiscal operations for general, central, and local governments).

${ }^{16}$ Karlan and Zinman (2009) used similar strategies using field experiment data to disentangle adverse selection from moral hazard to explain the default risk of consumer loans in South Africa. In my context, the provision of guarantees in PPP contracts may potentially affect firm's efforts in managing PPPs (i.e., possible moral hazard effect). However, conditional on contracts that receives guarantees, the difference in hazard rate between high vs. low PIM group identifies pure adverse selection effect.

${ }^{17}$ The results of this section remain robust when the outcome variable is replaced with the government-led disputes. The additional results are available upon request.
} 


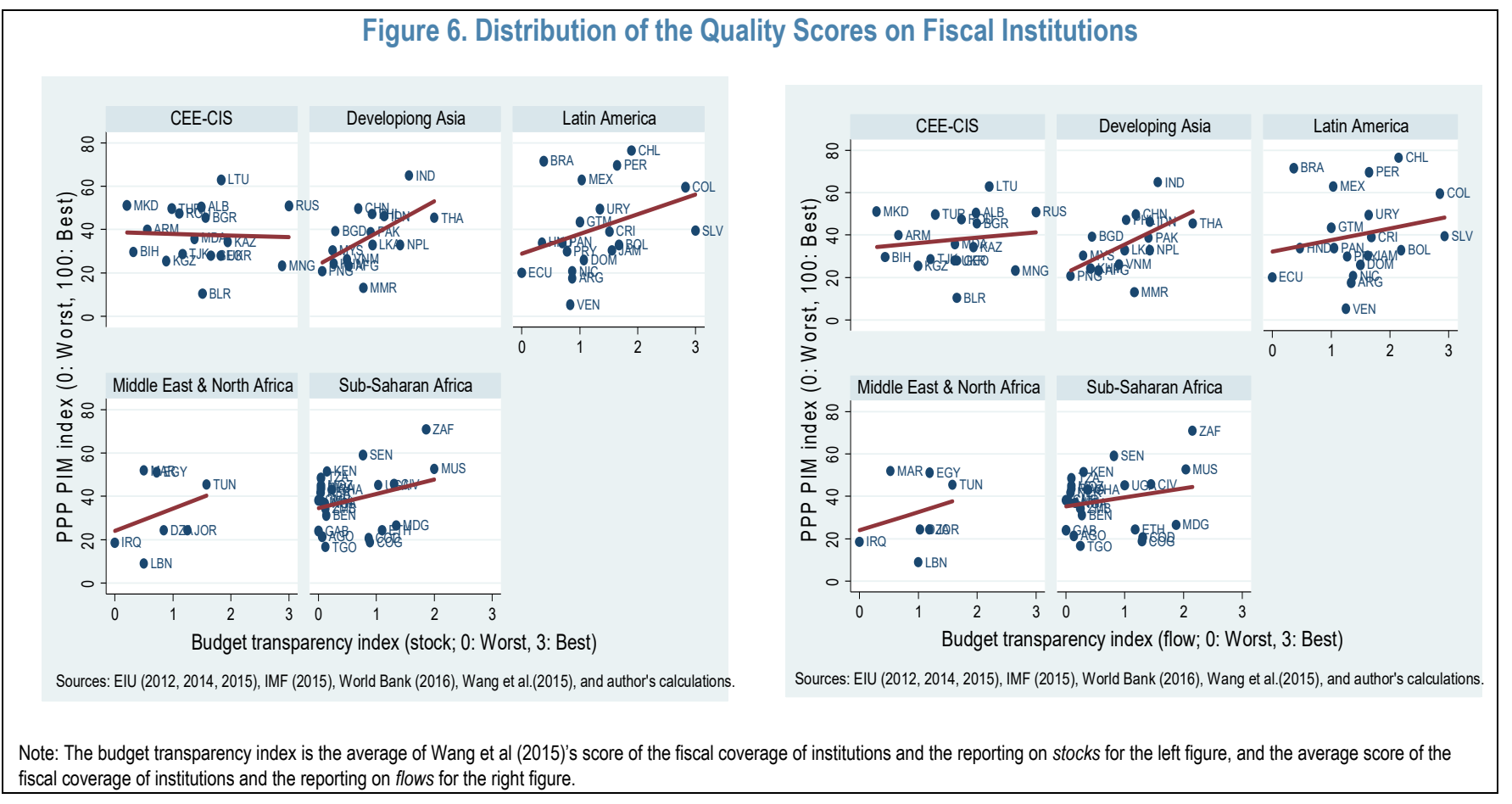

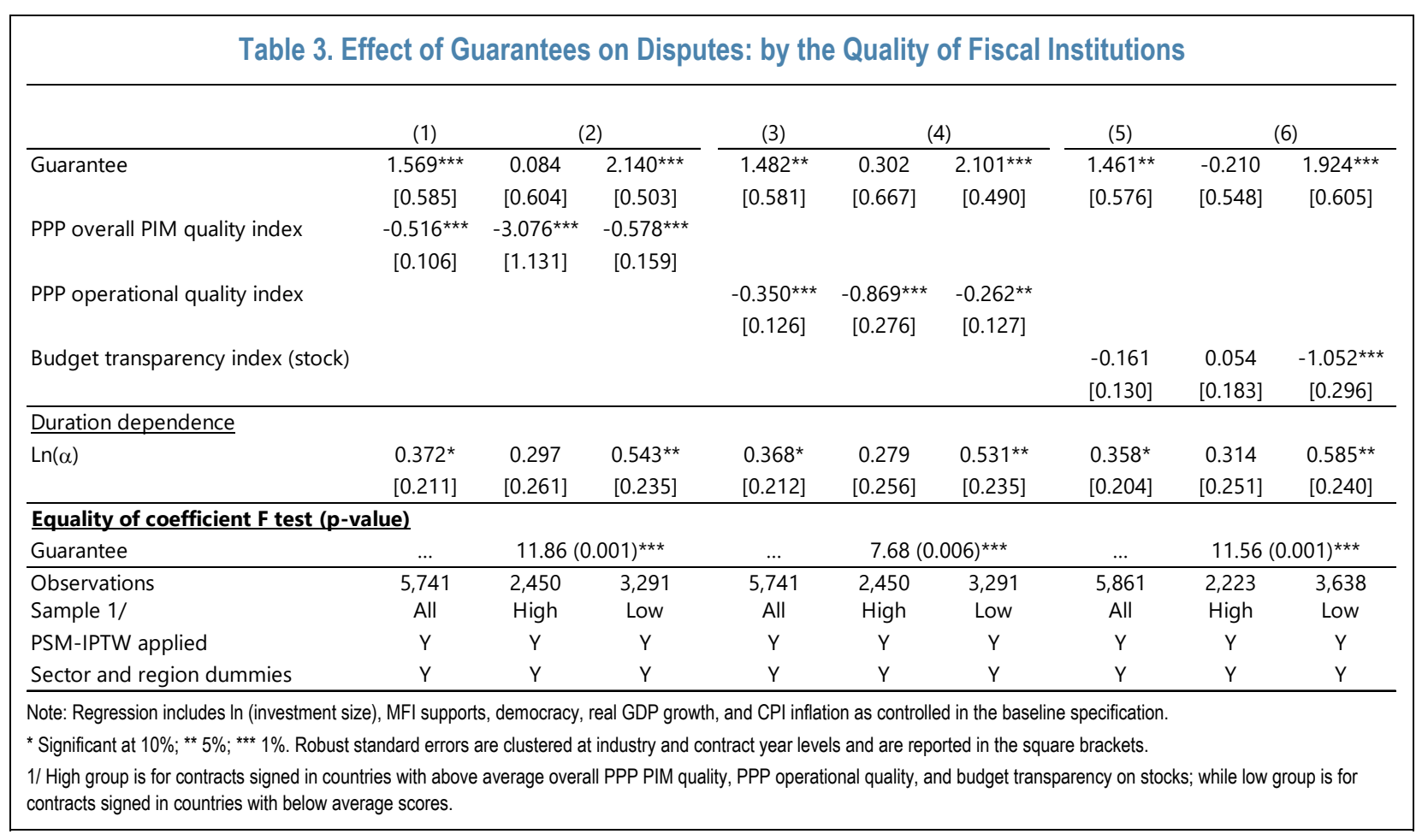

\section{CInternational Monetary Fund. Not for Redistribution}




\section{Conclusions}

Private participation in public services has become a critical feature to help reducing infrastructure gaps and improving the efficiency of public investment. Despite the attractiveness of PPPs as an alternative to conventional public finance projects, disputes between the government and private investors often result in large efficiency losses. Using a contract-level dataset, this paper examined how the government's fiscal commitments and the quality of fiscal institutions affect the risk of contractual disputes for PPPs.

First, the probit regression shows that larger government financing needs, lower budget transparency and bureaucratic efficiency are associated with higher probability for governments to offer guarantees. Second, propensity score matching results show that disputes tend to increase for guaranteed contracts due to higher fiscal risks, reflecting negative adverse selection and contingent liability effects. PPP management quality and budget transparency are found to be key determinants of the survival of PPPs. Finally, results also confirm previous empirical evidence that the involvement of MFIs and stronger political institutions help enforce PPP contracts.

Given that several emerging economies and most of commodity exporting developing countries face tight fiscal constraints, ensuring efficiency gains from PPPs through better selection and management of public investment, while minimizing the fiscal risk, is a highly relevant policy topic. The empirical analysis shows that many PPPs come along with guarantees, particularly in matured PPP markets, e.g., in developing Asia and Latin America, thereby increasing fiscal risk and triggering contract disputes. In sub-Saharan Africa, concessions have been more common and come with higher dispute risk due to lower project efficiency because of weak PIM quality. As PPP contracts with government guarantees start to gradually increase in the SSA, my finding suggests that SSA countries could also run larger dispute risks, as experienced in other emerging countries, in next 5-10 years. Although the policy priority differs by region, improving structural weakness in both budget transparency and the PIM quality is prerequisite for maximizing the efficiency of PPPs over the medium-term. In the short-term, drafting contracts with support from multilateral institutions could also help emerging and low income countries promote PPPs to fill infrastructure gap while ensuring fiscal and debt sustainability. 


\section{References}

Acemoglu, D. and Robinson, J., 2005 Economic Origins of Dictatorship and Democracy, Cambridge University Press

Arezki, R. and Gylfason, T., 2011, Resource Rents, Democracy and Corruption: Evidence from Sub-Saharan Africa, CESifo Working Paper \#3575

Austin, 2013, The Performance of Different Propensity Score Methods for Estimating Marginal Hazard Ratios. Statistics in Medicine, 32(16), pp. 2837-49.

Besley, T. and S. Coate, 1997, An Economic Model of Representative Democracy. Quarterly Journal of Economics 112(1): 85-114.

Besley, T. and Ghatak, M., 2010, Property Rights and Economic Development, in Chapter 68, Handbook of Development Economics, vol. 5

Besley, T. and Kudamatsu, M., 2008, Making Autocracy Work. Institutions and Economic Performance, edited by Elhanan Helpman (Havard University Press, 2008).

Besley, T. and Persson, T., 2009, The Origins of State Capacity: Property Rights, Taxation, and Politics, American Economic Review, vol. 99, no. 4, pp. 1218-44 , 2010, State Capacity, Conflict, and Development, Econometrica, 78(1), pp. 1-34

Cangiano, M., Alier, M., Anderson, B., Hemming, R., and Petrie, M., 2006, Public-private Partnerships, Government Guarantees, and Fiscal Risk. (Washington: International Monetary Fund).

Dabla-Norris, E., Brumby, J., Kyobe, A., Mills, Z., and Papageorgiou, C., 2012, Investing in Public Investment: An Index of Public Investment Efficiency. Journal of Economic Growth. 17, pp. 235-66.

Economist Intelligent Unit, 2012, 2014, 2015, Evaluating the Environment for Public-private Partnerships: The 2012, 2014, and 2015 Infrascope.

Eden, M., Kraay, A., and Qian, R., 2012, Sovereign Defaults and Expropriations: Empirical Regularities, World Bank Policy Research Working Paper, \#6218 (Washington: World Bank).

Engel, E., Fischer, R. and Galetovic, A., 2014, The Economics of Public-Private Partnerships: A Basic Guide, Cambridge University Press, (New York: Cambridge University)

Frankel, J., 2012, The Natural Resource curse: A Survey of Diagnoses and Some Prescriptions, in Chapter 2 of "Commodity Price Volatility and Inclusive Growth in Low-Income Countries" (Washington: International Monetary Fund).

Flyvbjerg, B., 2009, Survival of the Unfittest: Why the Worst Infrastructure Gets Built and What We can do about It. Oxford Review of Economic Policy. 25(3), pp. 344-67.

Gayat, E., Resche-Rigon, M., Mary JY., Porcher, R., 2012, Propensity Score Applied to Survival Data Analysis through Proportional Hazards Models: A Monte Carlo Study. Pharmaceutical Statistics. 11(3), pp. 222-29. 
Guasch, L., Laffont, J., and Straub, S., 2007, Concessions of Infrastructure in Latin America: Government-led Renegotiation. Journal of Applied Econometrics. 22, pp. 1267-94.

Hart, O., 2003, Incomplete Contracts and Public Ownership: Remarks and an Application to Public-Private Partnerships, Economic Journal, 113, pp. 69-76.

Humphreys, M. and Bates, R., 2005, Political Institutions and Economic Policies: Lessons from Africa. British Journal of Political Science, 35(03), pp. 403-28.

IMF, 2014a, World Economic Outlook: Legacies, Clouds, Uncertainties, Chapter 3 "Is It Time for an Infrastructure Push? The Macroeconomic Effects of Public Investment", (Washington: International Monetary Fund).

, 2014b, Fiscal Monitor: Public Expenditure Reform: Making Difficult Choices, Chapter 2 "Public Expenditure Reform" (Washington: International Monetary Fund).

, 2015, Toward More Efficient Public Investment (Washington: International Monetary Fund).

Iossa, E. and Martimont, D., 2015, The Simple Micro-Economics of Public-Private Partnership. Journal of Public Economic Theory, 17(1), pp. 4-48.

Jensen, N., 2008, Political Risk, Democratic Institutions, and Foreign Direct Investment. The Journal of Politics, 70(4), 1040-52.

and Johnston, N., 2011, Political Risk, Reputation and the Resource Curse, Comparative Political Studies, 44(6), pp. 662-88

, Johnston, N., Lee, C., and Sahin, A., 2017, Crisis and Contract Breach: The Domestic and International Determinants of Expropriation, mimeo

Karlan, D. and Zinman, J., 2009, Observing Unobservables: Identifying Information Asymmetries with a Consumer Credit Field Experiment. Econometrica, 77(6), pp 1993-2008

Li, Q., 2009, Democracy, Autocracy, and Expropriation of Foreign Direct Investment. Comparative Political Studies, 42(8), pp. 1098-208.

and Resnick, A., 2003, Reversal of Fortunes: Democratic Institutions and Foreign Direct Investment Inflows to Developing Countries. International Organization, 57(1), pp 175-211.

Maskin, E. and Tirole, J., 2008, Public-private Partnerships and Government Spending Limits, International Journal of Industrial Organization, 26(2), pp. 412-20.

Milesi-Ferretti, G. M., 2003, Goods, Bad, or Ugly? On the Effects of Fiscal Rules with Creative Accounting, Journal of Public Economics, 88, pp. 377-94.

Nose, M., 2014, Triggers of Contract Breach: Contract Design, Shocks, or Institutions? World Bank Policy Research Working Paper \#6738 (Washington: World Bank)

Nose, N., Queiroz, C., and Nose, M., 2017, Fiscal Commitments to Encourage PPP Projects in Transport Infrastructure, in "Transport Infrastructure and Systems" (London: Taylor \& Francis Group) 
Osborne, M. J., and A. Slivinski., 1996, A Model of Political Competition with CitizenCandidates. Quarterly Journal of Economics 111(1): 65-96.

Rosenbaum, P. and Rubin, D., 1983, The Central Role of the Propensity Score in Observational Studies for Causal Effects, Biometrika, 70, pp. 41-50.

Sabol, P. and Puentes, R., 2014, Private Capital, Public Good: Drivers of Successful Infrastructure Public-Private Partnerships, Brookings Institution (Washington)

Tomz, M. and Wright, M., 2010, Sovereign Theft: Theory and Evidence about Sovereign Default and Expropriation, in the Natural Resources Trap: Private Investment without Public Commitment, eds. Cambridge, MA: MIT Press, pp. 69-110

Valero, V., 2015, Government Opportunism in Public-Private Partnerships. Journal of Public Economic Theory, 17(1), pp. 111-35.

Wang, R., Irwin, T., and Murara, L., 2015, Trends in Fiscal Transparency: Evidence from a New Database of the Coverage of Fiscal Reporting. IMF Working Paper WP/15/188 (Washington: International Monetary Fund).

Woodhouse, E., 2006, The Obsolescing Bargain Redux? Foreign Investment in the Electric Power Sector in Developing Countries, International Law and Politics, vol. 38, 121.

World Bank, 2014a, The Power of Public Investment Management: Transforming Resources into Assets for Growth (Washington: World Bank).

, 2014b, Public-Private Partnerships Reference Guide version 2, World Bank Institute and PPIAF (Washington: World Bank).

, 2016, Benchmarking Public-Private Partnerships Procurement 2017 (Washington: World Bank). 


\section{TECHNICAL ANNEX}

\section{A. Country Groupings}

From all countries, available in PPI database, it chooses 113 emerging and developing countries as shown in Table A1 (categorized by income groups).

Table A1. All Sample: Country Classifications

\begin{tabular}{|c|c|c|c|c|c|}
\hline \multicolumn{2}{|c|}{ Low income (31) } & \multicolumn{2}{|c|}{ Lower middle income (43) } & \multicolumn{2}{|c|}{ Upper middle income (39) } \\
\hline Afghanistan & 7 & Angola & 8 & Albania & 15 \\
\hline Bangladesh & 59 & Armenia & 7 & Algeria & 22 \\
\hline Benin & 8 & Belize & 3 & Argentina & 178 \\
\hline Burkina Faso & 3 & Bhutan & 2 & Azerbaijan & 7 \\
\hline Burundi & 4 & Bolivia & 17 & Belarus & 4 \\
\hline Cambodia & 31 & Cameroon & 8 & Bosnia and Herzegovina & 4 \\
\hline Central African Republic & 3 & Cape Verde & 2 & Botswana & 3 \\
\hline Chad & 3 & Congo, Rep. & 7 & Brazil & 775 \\
\hline Comoros & 3 & Cote d'Ivoire & 16 & Bulgaria & 48 \\
\hline Congo, Dem. Rep. & 10 & Djibouti & 3 & Chile & 194 \\
\hline Ethiopia & 3 & Egypt, Arab Rep. & 21 & China & 1,148 \\
\hline Gambia, The & 2 & El Salvador & 12 & Colombia & 136 \\
\hline Guinea & 7 & Georgia & 15 & Costa Rica & 40 \\
\hline Guinea-Bissau & 2 & Ghana & 16 & Dominican Republic & 29 \\
\hline Kenya & 20 & Guatemala & 34 & Ecuador & 27 \\
\hline Kyrgyz Republic & 6 & Honduras & 30 & Gabon & 12 \\
\hline Liberia & 8 & India & 870 & Iran, Islamic Rep. & 8 \\
\hline Madagascar & 9 & Indonesia & 110 & Jamaica & 14 \\
\hline Malawi & 4 & Iraq & 13 & Jordan & 27 \\
\hline Mali & 2 & Lao PDR & 29 & Kazakhstan & 8 \\
\hline Mozambique & 12 & Lesotho & 1 & Lebanon & 3 \\
\hline Myanmar & 7 & Mauritania & 2 & Lithuania & 8 \\
\hline Nepal & 36 & Moldova & 5 & Macedonia, FYR & 4 \\
\hline Niger & 4 & Mongolia & 4 & Malaysia & 107 \\
\hline Rwanda & 9 & Morocco & 20 & Maldives & 3 \\
\hline Sierra Leone & 7 & Nicaragua & 17 & Mauritius & 12 \\
\hline Tajikistan & 8 & Nigeria & 55 & Mexico & 260 \\
\hline Tanzania & 25 & Pakistan & 87 & Namibia & 1 \\
\hline Togo & 7 & Papua New Guinea & 3 & Panama & 26 \\
\hline Uganda & 27 & Paraguay & 5 & Peru & 109 \\
\hline Zimbabwe & 5 & Philippines & 119 & Romania & 42 \\
\hline & & Senegal & 16 & Russian Federation & 119 \\
\hline & & Sri Lanka & 87 & Seychelles & 3 \\
\hline & & Sudan & 6 & South Africa & 79 \\
\hline & & Swaziland & 1 & Thailand & 153 \\
\hline & & Syrian Arab Republic & 3 & Tunisia & 9 \\
\hline & & Tonga & 3 & Turkey & 176 \\
\hline & & Turkmenistan & 1 & Uruguay & 36 \\
\hline & & Ukraine & 30 & Venezuela, RB & 12 \\
\hline & & Uzbekistan & 8 & & \\
\hline & & Vietnam & 86 & & \\
\hline & & Yemen, Rep. & 8 & & \\
\hline & & Zambia & 7 & & \\
\hline Total number of PPPs & 341 & & 1,797 & & 3,861 \\
\hline
\end{tabular}

Note: Number of PPP contracts (greenfield projects and concessions) are listed next to country name. 


\section{B. Map}

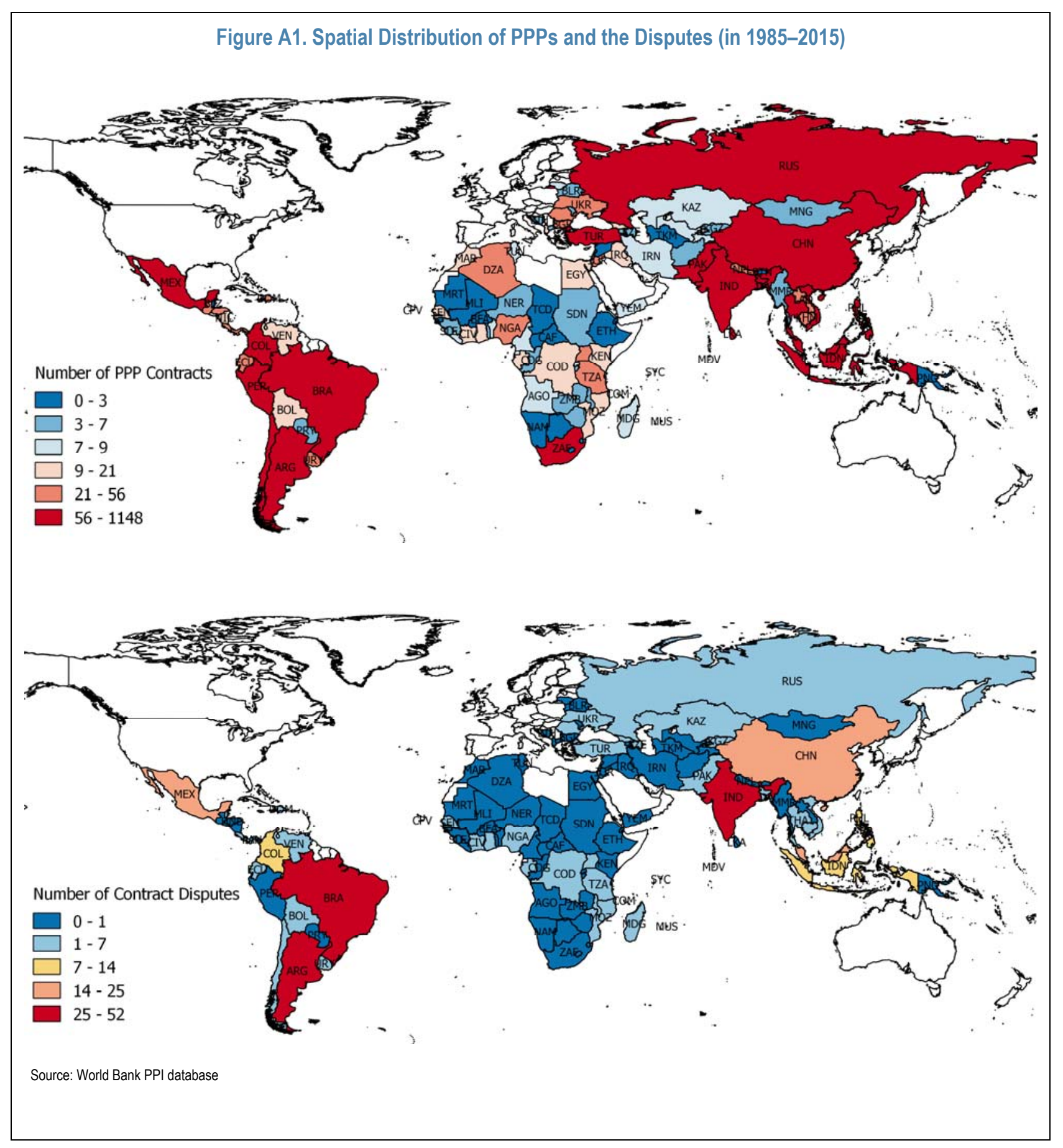




\section{Summary Statistics}

Table A2 reports summary statistics of the main variables. Full sample includes 5,999 PPP contracts, of which most contracts were signed in developing Asia and Latin American countries and in energy or transport sectors. Total disputes occurred for about $6 \frac{1}{2}$ percent of the contract.

The dataset has details on the characteristics of PPP contracts, including project status (e.g., completed, under construction, cancelled, in distress), the financial closure year, timing of disputes, contract period, sectors, procurement type, the type of guarantees, direct subsidies, financial arrangements with MFIs, and sponsors' originating country. Although only 13 percent of contracts receive guarantees on average, the issuance of guarantees has significantly increased since 2000 s especially after the 2007-08 global financial crisis (see Figure 3). Guarantees were provided mainly with payment guarantee (80 percent), revenue guarantee (11 percent), or tariff rate guarantee (4 percent). The government provided direct subsidies to PPP projects with about 12 percent of the contracts. Only 13 percent of the contracts involved MFIs which were more common before 2000s.

About 65 percent of contracts in MICs and LICs fully or partially involved local investors. Local investor's participation in PPP contract is the most common in developing Asia (78 percent), for example in India, Malaysia, China, Thailand, and Sri Lanka where about 80-90 percent of contracts are sponsored by local investors.

The cyclical factors such as GDP growth and CPI inflation during the contract would affect the performance of PPPs. In the sample, the average growth rate is positive at 5.4 percent, while the average inflation is 9.3 percent. The GFN (in percent of GDP) is 11 percent on average with a range of 0.3 to 102.2 percent. The public debt (in percent of GDP) is 49.2 percent on average. On the country's political institutions, many countries are democratic (democracy score above 10) and the average length of national leaders in the office is about 5 years with a range of 1 to 34 years. About 23 percent is classified as commodity (either oil, gas, or coal) exporting countries. 


\begin{tabular}{|c|c|c|c|c|c|c|}
\hline \multicolumn{7}{|c|}{ Table A2. Summary Statistics, Full Sample } \\
\hline & $\mathbf{N}$ & Mean & Std. dev & Median & Min & Max \\
\hline Disputes & 5,999 & 0.064 & 0.244 & 0 & 0 & 1 \\
\hline Government-led disputes & 4,598 & 0.044 & 0.205 & 0 & 0 & 1 \\
\hline \multicolumn{7}{|l|}{ Micro variables } \\
\hline Contract duration (year) & 5,999 & 9.1 & 6.5 & 8 & 0.5 & 34 \\
\hline Investment size (in mil USD) & 5,999 & 339.4 & $1,151.1$ & 77.5 & 0.0 & $35,586.5$ \\
\hline Sponsor with same nationality & 5,999 & 0.646 & 0.478 & 1 & 0 & 1 \\
\hline Government guarantees & 5,999 & 0.127 & 0.333 & 0 & 0 & 1 \\
\hline Direct subsidy & 5,999 & 0.121 & 0.326 & 0 & 0 & 1 \\
\hline Concession & 5,999 & 0.271 & 0.444 & 0 & 0 & 1 \\
\hline MFI supports & 5,999 & 0.126 & 0.332 & 0 & 0 & 1 \\
\hline \multicolumn{7}{|l|}{ Macro variables } \\
\hline Log GDP per capita in 2000 & 5,940 & 8.487 & 0.635 & 8.331 & 5.790 & 9.762 \\
\hline Real GDP growth (\%) & 5,998 & 5.4 & 2.3 & 5.6 & -9.9 & 11.0 \\
\hline CPI inflation (\%) & 5,997 & 9.3 & 10.2 & 7.7 & -1.0 & 135.0 \\
\hline Democracy & 5,979 & 13.8 & 6.3 & 17.3 & 1 & 20 \\
\hline Duration of national leader (year) & 5,992 & 5.3 & 3.5 & 4.5 & 1 & 34 \\
\hline GFN/GDP (\%) & 5,967 & 10.9 & 7.0 & 11.8 & 0.3 & 102.2 \\
\hline Public debt/GDP (\%) & 5,958 & 49.2 & 20.5 & 42.7 & 0.0 & 163.4 \\
\hline PPP capital stock/GDP (\%) & 5,681 & 3.6 & 5.4 & 2.2 & 0.0 & 94.5 \\
\hline Commodity exporter & 5,999 & 0.232 & 0.422 & 0 & 0 & 1 \\
\hline Regulatory quality & 5,999 & -0.109 & 0.495 & -0.219 & -2.410 & 1.483 \\
\hline Bureaucratic efficiency & 5,999 & -0.042 & 0.445 & -0.061 & -1.970 & 1.216 \\
\hline PPP PFM quality $1 /$ & 5,853 & 0.001 & 1.000 & -0.173 & -3.016 & 1.527 \\
\hline PPP operational quality 1 / & 5,853 & 0.001 & 0.999 & 0.555 & -2.889 & 0.972 \\
\hline Budget transprency index (flow) 1/ & 5,999 & 0.009 & 0.995 & -0.040 & -1.830 & 2.666 \\
\hline Budget transprency index (stock) 1/ & 5,999 & 0.008 & 0.997 & -0.173 & -1.538 & 2.928 \\
\hline \multicolumn{7}{|l|}{ Sector dummies } \\
\hline Oil, gas, and mining & 5,999 & 0.051 & 0.221 & 0 & 0 & 1 \\
\hline Energy & 5,999 & 0.454 & 0.498 & 0 & 0 & 1 \\
\hline Transport & 5,999 & 0.259 & 0.438 & 0 & 0 & 1 \\
\hline Water & 5,999 & 0.129 & 0.335 & 0 & 0 & 1 \\
\hline Information and Communication & 5,999 & 0.107 & 0.309 & 0 & 0 & 1 \\
\hline \multicolumn{7}{|l|}{ Region dummies } \\
\hline Developing Asia & 5,999 & 0.491 & 0.500 & 0 & 0 & 1 \\
\hline Eastern Europe and CIS & 5,999 & 0.087 & 0.281 & 0 & 0 & 1 \\
\hline Latin America and the Caribbean & 5,999 & 0.326 & 0.469 & 0 & 0 & 1 \\
\hline Middle East and North Africa & 5,999 & 0.024 & 0.152 & 0 & 0 & 1 \\
\hline Sub-saharan Africa & 5,999 & 0.073 & 0.260 & 0 & 0 & 1 \\
\hline
\end{tabular}




\section{Balancing Test of PSM}

Table A3 describes the balancing tests for all contract characteristics before and after the application of the PSM. Column 1 shows t-test for treated (with guarantees) and control (without) group. After the PSM, almost all characteristics are well balanced. Column 2 shows the test for treatment by direct subsidies. After the PSM, all characteristics are balanced. For both treatments, the test of overall matching quality is presented at the bottom of the table. After the PSM, R-square declined close to zero (meaning no contract characteristics explains the probability of treatment) and mean standardized bias significantly declined, both support the validity of the PSM.

\begin{tabular}{|c|c|c|c|c|c|c|c|c|c|c|c|}
\hline \multirow[b]{3}{*}{ Variables } & \multirow{3}{*}{$\begin{array}{c}\text { Application } \\
\text { of PSM }\end{array}$} & \multicolumn{5}{|c|}{$\begin{array}{c}(1) \\
\text { Guarantee }\end{array}$} & \multicolumn{5}{|c|}{$\begin{array}{c}\text { (2) } \\
\text { Direct subsidy }\end{array}$} \\
\hline & & \multicolumn{2}{|c|}{ Mean } & & \multicolumn{2}{|l|}{$\mathrm{t}$-test } & \multicolumn{2}{|c|}{ Mean } & & \multicolumn{2}{|l|}{$t$-test } \\
\hline & & Treated & Control & \%bias & $\mathrm{t}$ & $p>|t|$ & Treated & Control & \%bias & $\mathrm{t}$ & $p>|t|$ \\
\hline \multirow[t]{2}{*}{ Ln(investment size) } & Before & 4.25 & 4.25 & -0.10 & -0.02 & 0.99 & 4.36 & 4.24 & 6.90 & 1.60 & 0.11 \\
\hline & After & 4.24 & 4.34 & -5.30 & -1.06 & 0.29 & 4.35 & 4.35 & 0.10 & 0.02 & 0.99 \\
\hline \multirow[t]{2}{*}{ Ln(GDP per capita in 2000) } & Before & 8.42 & 8.50 & -11.60 & $-2.87^{\star \star \star}$ & 0.00 & 8.33 & 8.51 & -30.60 & $-7.27 * \star \star$ & 0.00 \\
\hline & After & 8.43 & 8.43 & -1.10 & -0.22 & 0.83 & 8.33 & 8.33 & 0.20 & 0.05 & 0.96 \\
\hline \multirow[t]{2}{*}{$\operatorname{Ln}(G F N / G D P)$} & Before & 2.44 & 2.37 & 15.20 & $3.91^{\star \star \star}$ & 0.00 & 2.37 & 2.38 & -1.90 & -0.45 & 0.65 \\
\hline & After & 2.44 & 2.44 & -0.10 & -0.02 & 0.99 & 2.37 & 2.37 & 0.70 & 0.14 & 0.89 \\
\hline \multirow[t]{2}{*}{ Ln(public debt/GDP) } & Before & 3.88 & 3.81 & 15.50 & $3.69 * \star \star$ & 0.00 & 3.92 & 3.81 & 25.40 & $6.00^{* * *}$ & 0.00 \\
\hline & After & 3.88 & 3.87 & 4.40 & 0.97 & 0.33 & 3.92 & 3.91 & 2.20 & 0.47 & 0.64 \\
\hline \multirow[t]{2}{*}{ Regulatory quality } & Before & -0.14 & -0.10 & -6.90 & -1.74 * & 0.08 & -0.16 & -0.10 & -12.40 & $-2.96 * \star \star$ & 0.00 \\
\hline & After & -0.14 & -0.14 & -0.50 & -0.10 & 0.92 & -0.16 & -0.16 & 0.30 & 0.07 & 0.95 \\
\hline \multirow[t]{2}{*}{ Bureaucratic efficiency } & Before & -0.07 & -0.04 & -7.20 & $-1.80 *$ & 0.07 & 0.01 & -0.05 & 15.50 & $3.53^{* * *}$ & 0.00 \\
\hline & After & -0.06 & -0.08 & 3.30 & 0.65 & 0.52 & 0.02 & 0.02 & -1.10 & -0.26 & 0.79 \\
\hline \multirow[t]{2}{*}{ Commodity exporter } & Before & 0.22 & 0.23 & -2.60 & -0.67 & 0.50 & 0.21 & 0.23 & -5.60 & -1.39 & 0.17 \\
\hline & After & 0.22 & 0.23 & -3.20 & -0.61 & 0.54 & 0.21 & 0.21 & -0.20 & -0.04 & 0.97 \\
\hline \multirow[t]{2}{*}{ Sponsor with same nationality } & Before & 0.65 & 0.64 & 2.00 & 0.52 & 0.61 & 0.81 & 0.62 & 43.20 & $10.11 * * \star$ & 0.00 \\
\hline & After & 0.66 & 0.65 & 2.20 & 0.43 & 0.67 & 0.82 & 0.82 & -0.70 & -0.15 & 0.88 \\
\hline \multicolumn{12}{|l|}{$\underline{\text { Sector dummies }}$} \\
\hline \multirow[t]{2}{*}{ Energy } & Before & 0.82 & 0.40 & 94.60 & $22.54^{* * *}$ & 0.00 & 0.37 & 0.47 & -18.90 & 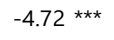 & 0.00 \\
\hline & After & 0.82 & 0.82 & -1.30 & -0.28 & 0.78 & 0.37 & 0.33 & 8.40 & 1.63 & 0.10 \\
\hline \multirow[t]{2}{*}{ Transport } & Before & 0.07 & 0.29 & -57.20 & -12.62 *** & 0.00 & 0.45 & 0.23 & 47.90 & $12.91 * * *$ & 0.00 \\
\hline & After & 0.07 & 0.08 & -0.60 & -0.17 & 0.86 & 0.46 & 0.48 & -4.80 & -0.84 & 0.40 \\
\hline \multirow[t]{2}{*}{ Water } & Before & 0.10 & 0.13 & -8.50 & -2.12 ** & 0.03 & 0.14 & 0.13 & 4.60 & 1.18 & 0.24 \\
\hline & After & 0.11 & 0.08 & 8.20 & 1.76 * & 0.08 & 0.14 & 0.15 & -2.90 & -0.54 & 0.59 \\
\hline \multicolumn{12}{|l|}{ Region dummies } \\
\hline \multirow[t]{2}{*}{ CEE-CIS } & Before & 0.10 & 0.08 & 6.60 & 1.78 * & 0.08 & 0.06 & 0.09 & -9.80 & -2.34 ** & 0.02 \\
\hline & After & 0.09 & 0.09 & 1.00 & 0.20 & 0.84 & 0.06 & 0.08 & -4.70 & -0.94 & 0.35 \\
\hline \multirow[t]{2}{*}{ Developing Asia } & Before & 0.55 & 0.48 & 14.30 & $3.70^{* * \star}$ & 0.00 & 0.63 & 0.47 & 33.30 & $8.28^{\star \star \star}$ & 0.00 \\
\hline & After & 0.56 & 0.55 & 1.30 & 0.26 & 0.80 & 0.63 & 0.64 & -1.30 & -0.25 & 0.81 \\
\hline \multirow[t]{2}{*}{ Latin America } & Before & 0.24 & 0.34 & -23.00 & $-5.70 * * *$ & 0.00 & 0.25 & 0.34 & -20.00 & $-4.87 * * \star$ & 0.00 \\
\hline & After & 0.24 & 0.24 & 0.90 & 0.19 & 0.85 & 0.25 & 0.23 & 4.90 & 0.99 & 0.32 \\
\hline Sub-saharan Africa & Before & 0.07 & 0.07 & -1.00 & -0.25 & 0.81 & 0.04 & 0.08 & -17.40 & $-3.92 * * \star$ & 0.00 \\
\hline & After & 0.07 & 0.09 & -9.40 & $-1.72 *$ & 0.09 & 0.04 & 0.04 & -0.80 & -0.19 & 0.85 \\
\hline & & Pseudo-R & R square & Mean st & andardized & | bias $1 /$ & Pseudo-F & R square & Mean sta & ndardized & bias \\
\hline Test matching quality & Before & & 0.200 & & 19.1 & & & 0.177 & & 21.8 & \\
\hline & After & & 0.013 & & 2.9 & & & 0.007 & & 2.2 & \\
\hline
\end{tabular}




\section{E. Derivation of the Shadow Price}

Dynamic optimization of Eq. (2) yields the following first-order condition with respect to $z_{t}$ :

$$
E_{t} \lambda_{t+1}=\beta\left[(1-\delta)-c_{2}-\chi_{2} p\left(\underline{q}-q_{t}\right)\right] E_{t+1} \lambda_{t+2}
$$

Using this condition with the budget constraint and Eq. (3), the shadow price is expressed as follows:

$$
E_{t} \lambda_{t+1}=\left(\frac{\alpha}{1-\varphi}\right)\left(\frac{\varphi}{r+c_{1}}\right)^{\frac{\varphi}{1-\varphi}} \beta^{\frac{1-\gamma}{1-\gamma-\varphi}}\left[\frac{1-\frac{1-\delta-c_{2}-\chi_{2} p\left(q-q_{t}\right)}{\left[\beta\left(c_{2}+\chi_{2} p\left(\underline{q}-q_{t}\right)-(1-\delta)\right)\right]^{\frac{1-\varphi}{1-\gamma-\varphi}}}}{L+T_{t}-\mu \bar{\alpha}}\right]^{\frac{1-\gamma-\varphi}{1-\varphi}}
$$

Partial derivatives of the shadow price yields three comparative statics: $\frac{\partial E_{t} \lambda_{t+1}}{\partial T_{t}}<0, \frac{\partial E_{t} \lambda_{t+1}}{\partial \bar{\alpha}}>0$ and $\frac{\partial E_{t} \lambda_{t+1}}{\partial \chi_{2}}>0$ 


\section{F. Role of PPP Investment Management in case of Concessions}

Results in Table 3 highlight that PPP investment management and budget transparency are important in avoiding negative adverse selection of guaranteed projects. Besides guarantees, Table 2 and Figure 5 highlight that concessions also tend to increase disputes especially in SSA countries.

Using the same hazard regression as in section V.D, Table A.4 shows whether the survival rate of concession contracts depends on the overall PIM quality and PPP operational quality. The negative interaction term indicates that dispute risk decreases as a country improves its PPP investment management practices. This result underscores that the PIM quality is also an important determinant of the success in concession contracts.

Table A.4: Effect of Concessions on Disputes: by the Quality of Fiscal Institutions

\begin{tabular}{|c|c|c|}
\hline & \multicolumn{2}{|c|}{ All disputes } \\
\hline & $(1)$ & (2) \\
\hline \multirow[t]{2}{*}{ Concessions } & $1.805^{\star \star \star}$ & $1.522^{\star \star \star}$ \\
\hline & {$[0.362]$} & {$[0.344]$} \\
\hline \multirow[t]{2}{*}{ x PPP overall PIM quality index } & $-0.797^{\star \star}$ & \\
\hline & {$[0.336]$} & \\
\hline \multirow[t]{2}{*}{ x PPP operational quality index } & & $-1.180^{\star * *}$ \\
\hline & & [0.324] \\
\hline \multicolumn{3}{|l|}{ Duration dependence } \\
\hline \multirow[t]{2}{*}{$\operatorname{Ln}(\alpha)$} & 0.096 & 0.114 \\
\hline & {$[0.138]$} & {$[0.155]$} \\
\hline Observations & 5,741 & 5,741 \\
\hline Sample 1/ & All & All \\
\hline PSM-IPTW applied & Y & $\mathrm{Y}$ \\
\hline Sector and region dummies & $\mathrm{Y}$ & Y \\
\hline
\end{tabular}

Note: Regression includes In (investment size), MFI supports, democracy, real GDP growth, and CPI inflation as controlled in the baseline specification.

* Significant at $10 \%$; ** $5 \%$; *** $1 \%$. Robust standard errors are clustered at industry and contract year levels and are reported in the square brackets. 